\title{
Purinergic receptors and gastrointestinal secretomotor function
}

\author{
Fievos Leontiou Christofi
}

Received: 17 May 2007 / Accepted: 7 April 2008 / Published online: 5 July 2008

(C) Springer Science + Business Media B.V. 2008

\begin{abstract}
Secretomotor reflexes in the gastrointestinal (GI) tract are important in the lubrication and movement of digested products, absorption of nutrients, or the diarrhea that occurs in diseases to flush out unwanted microbes. Mechanical or chemical stimulation of mucosal sensory enterochromaffin (EC) cells triggers release of serotonin (5-HT) (among other mediators) and initiates local reflexes by activating intrinsic primary afferent neurons of the submucous plexus. Signals are conveyed to interneurons or secretomotor neurons to stimulate chloride and fluid secretion. Inputs from myenteric neurons modulate secretory rates and reflexes, and special neural circuits exist to coordinate secretion with motility. Cellular components of secretomotor reflexes variably express purinergic receptors for adenosine (A1, $\mathrm{A} 2 \mathrm{a}, \mathrm{A} 2 \mathrm{~b}$, or $\mathrm{A} 3$ receptors) or the nucleotides adenosine 5 '-triphosphate (ATP), adenosine diphosphate (ADP), uridine 5'-triphosphate (UTP), or uridine diphosphate (UDP) ( $\mathrm{P}_{1-7}, \mathrm{P}_{1} \mathrm{Y}_{2}, \mathrm{P}_{2} \mathrm{Y}_{4}, \mathrm{P} 2 \mathrm{Y}_{6}$, $\mathrm{P} 2 \mathrm{Y}_{12}$ receptors). This review focuses on the emerging concepts in our understanding of purinergic regulation at these receptors, and in particular of mechanosensory reflexes. Purinergic inhibitory $\left(\mathrm{A}_{1}, \mathrm{~A}_{3}, \mathrm{P} 2 \mathrm{Y}_{12}\right)$ or excitatory
\end{abstract}

\footnotetext{
F. L. Christofi

Columbus, OH 43210, USA

F. L. Christofi $(\bowtie)$

College of Medicine and Public Health,

The Ohio State University,

226 Tzagournis Medical Research Facility,

420 West 12th Avenue,

Columbus, OH 43210, USA

e-mail: christofi.1@osu.edu
}

Department of Anesthesiology, The Ohio State University,
$\left(\mathrm{A}_{2}, \mathrm{P} 2 \mathrm{Y}_{1}\right)$ receptors modulate mechanosensitive 5-HT release. Excitatory $\left(\mathrm{P}_{2} \mathrm{Y}_{1}\right.$, other $\left.\mathrm{P} 2 \mathrm{Y}, \mathrm{P} 2 \mathrm{X}\right)$ or inhibitory $\left(\mathrm{A}_{1}, \mathrm{~A}_{3}\right)$ receptors are involved in mechanically evoked secretory reflexes or "neurogenic diarrhea." Distinct neural (pre- or postsynaptic) and non-neural distribution profiles of $\mathrm{P} 2 \mathrm{X}_{2}, \mathrm{P} 2 \mathrm{X}_{3}, \mathrm{P} 2 \mathrm{X}_{5}, \mathrm{P}_{2} \mathrm{Y}_{1}, \mathrm{P}_{2} \mathrm{Y}_{2}, \mathrm{P}_{2} \mathrm{Y}_{4}, \mathrm{P}_{2} \mathrm{Y}_{6}$, or P2 $\mathrm{Y}_{12}$ receptors, and for some their effects on neurotransmission, suggests their role in GI secretomotor function. Luminal $\mathrm{A}_{2 \mathrm{~b}}, \mathrm{P} 2 \mathrm{Y}_{2}, \mathrm{P}_{2} \mathrm{Y}_{4}$, and $\mathrm{P} 2 \mathrm{Y}_{6}$ receptors are involved in fluid and $\mathrm{Cl}^{-}, \mathrm{HCO}_{3}^{-}, \mathrm{K}^{+}$, or mucin secretion. Abnormal receptor expression in GI diseases may be of clinical relevance. Adenosine $A_{2 a}$ or $A_{3}$ receptors are emerging as therapeutic targets in inflammatory bowel diseases (IBD) and gastroprotection; they can also prevent purinergic receptor abnormalities and diarrhea. Purines are emerging as fundamental regulators of enteric secretomotor reflexes in health and disease.

Keywords Chloride secretion - Gastrointestinal tract . Enterochromaffin cells - 5-HT release - Submucous plexus . Epithelial cells · Mucosal reflex · Mechanosensitivity · Purinergic receptors $\cdot \mathrm{P} 2 \mathrm{X}$ receptors $\cdot \mathrm{P} 2 \mathrm{Y}$ receptors . Adenosine receptors

$\begin{array}{ll}\begin{array}{l}\text { Abbreviations } \\ \text { 5-HT }\end{array} & \begin{array}{l}\text { serotonin } \\ \text { adenosine deaminase }\end{array} \\ \text { ADA } & \text { adenosine kinase } \\ \text { AK } & N 6 \text {-(2-methylthioethyl)-2-(3,3, } \\ \text { AR-C69931MX or } & 3 \text {-trifluoropropylthio)- } \beta \gamma- \\ \text { cangrelor } & \text { dichloromethylene-ATP } \\ & \text { adenosine 5'-triphosphate } \\ \text { ATP } & \mathrm{Ca}^{2+} \text {-dependent } \mathrm{Cl}^{-} \text {channels } \\ \text { CaCC } & 3^{\prime}, 5^{\prime} \text {-cyclic adenosine monophosphate }\end{array}$




\begin{tabular}{|c|c|}
\hline CFTR & $\begin{array}{l}\text { cystic fibrosis conductance } \\
\text { transmembrane regulator }\end{array}$ \\
\hline ChaT & choline acetyltransferase \\
\hline $\mathrm{EC}$ & enterochromaffin cell \\
\hline $\mathrm{ENaC}$ & $\begin{array}{l}\text { amiloride-sensitive epithelial } \mathrm{Na}^{+} \\
\text {channels }\end{array}$ \\
\hline ENS & enteric nervous system \\
\hline EPAN & extrinsic primary afferent neuron \\
\hline GI & gastrointestinal tract \\
\hline IBD & inflammatory bowel diseases \\
\hline IPAN & intrinsic primary afferent neuron \\
\hline -ir & immunoreactivity \\
\hline Isc & $\begin{array}{l}\text { short-circuit current indicative of } \\
\text { chloride secretion }\end{array}$ \\
\hline 2MeSADP & 2-methylthioADP \\
\hline MRS2279 & $\begin{array}{l}\text { 2-chloro-N6-methyl- }(N) \text { - } \\
\text { methanocarba-2'-deoxyadenosine- } \\
\text { 3'5'-bisphosphate }\end{array}$ \\
\hline MRS2179 & $\begin{array}{l}\text { 2'-deoxy-N6-methyladenosine- } \\
\text { 3'5'-bisphosphate }\end{array}$ \\
\hline MRS2211 & $\begin{array}{l}\text { 6-(2'-chloro-5-nitro-azophenyl)- } \\
\text { pyridoxal- } \alpha 5 \text {-phosphate }\end{array}$ \\
\hline MRS2567 & $\begin{array}{l}\text { 1.2-di-(4-isothio-cyanatophenyl) } \\
\text { ethane }\end{array}$ \\
\hline NBTI & $S$-(p-nitrobenzyl)-6-thioinosine \\
\hline NPY & neuropeptide Y \\
\hline PLC & phospholipase C \\
\hline PPADS & $\begin{array}{l}\text { pyridoxal phosphate-6-azo(benzene- } \\
\text { 2,4-disulfonic acid) tetrasodium salt }\end{array}$ \\
\hline $\mathrm{R}$ & receptor \\
\hline SP & substance $\mathrm{P}$ \\
\hline VIP & vasoactive intestinal peptide \\
\hline
\end{tabular}

\section{Introduction}

Gastrointestinal (GI) secretions in coordination with motility are important in digestion of food particles, lubrication, nutrient absorption, regulation of $\mathrm{pH}$ and solute concentration, and elimination of waste products. Diarrhea occurs in GI diseases to flush out noxious chemicals or unwanted microbes. Intestinal chloride secretion provides a driving force for fluid movement and obligate transport of water into the lumen. Under normal circumstances, mucosal chloride secretion is very low, but can reach extraordinary rates when challenged by enterotoxins or various secretogogues. Hallmarks of enteric infections or inflammatory bowel diseases (IBD) are malaise and diarrhea; the other extreme is constipation that occurs in patients with idiopathic constipation, constipation-predominant irritable bowel syndrome (IBS), or opioid-induced constipation.
Structural or functional changes in the enteric nervous system (ENS), in neurotransmitters, signaling pathways, or other components of enteric neural reflexes may be the basis for the pathogenesis of disturbances in gut motor function.

The current review will focus primarily on the role of purines in secretomotor function in the GI system. The enterochromaffin-neural circuit-epithelial reflex pathway is our target for understanding secretomotor function in the intestinal tract. All cellular components of mucosal reflexes express purinergic receptors, and this review will focus on these receptors, their distribution, and function in mucosal reflexes and secretomotor function in the GI tract. The enteric neural circuits and cellular components involved in neurosecretory reflexes will first be briefly reviewed. A brief overview and basic knowledge of purinoceptor classification, pharmacology, receptor ligands and their selectivity is necessary in order to understand the concepts forwarded in this review. Emerging concepts will be reviewed in our understanding of purinergic regulation in mucosal reflexes, with particular emphasis on enterochromaffin cells (EC), mucosal reflexes, receptor distribution, and luminal P2 receptors involved in epithelial ion transport and fluid secretion. In addition, we review recent findings on purinergic regulation of gastric secretions, and in relation to gastric mucosal protection. Our review would not be complete without a very brief description of the emerging role of purinergic receptors as therapeutic targets in IBD [2] or implications of purine receptor abnormalities (up- or downregulation) in GI diarrhea diseases. The reader is also referred to more general reviews on purinergic signaling [12], GI secretomotor function and dysfunction $[25,26]$, epithelial secretion, and hepatobiliary function [92]. Other relevant reviews include adenosine neuromodulation [20], purines in mechanosensory signaling [26], ATP as a sensory transmitter [6], and $\mathrm{P}_{2} \mathrm{Y}_{1}$ receptors in secretomotor function [113], or P2X receptors as potential targets in IBS [40].

\section{Enterochromaffin-neural-epithelial reflex pathways}

The secretory reflex is composed of sensory EC cells, intrinsic primary afferent neurons (IPANs), various interneurons, secretomotor neurons, interplexus neurons for coordinating secretion and motility or for secretomotor function [11], and the epithelial cells involved in ion transport and fluid secretion in the gut lumen (Fig. 1). Luminal stimulation by nutrients, changes in $\mathrm{pH}$, mechanical forces, changes in solute concentration, luminal irritants, or invading enteropathogenic microorganisms will activate the EC cells to secrete serotonin (5-HT) among 


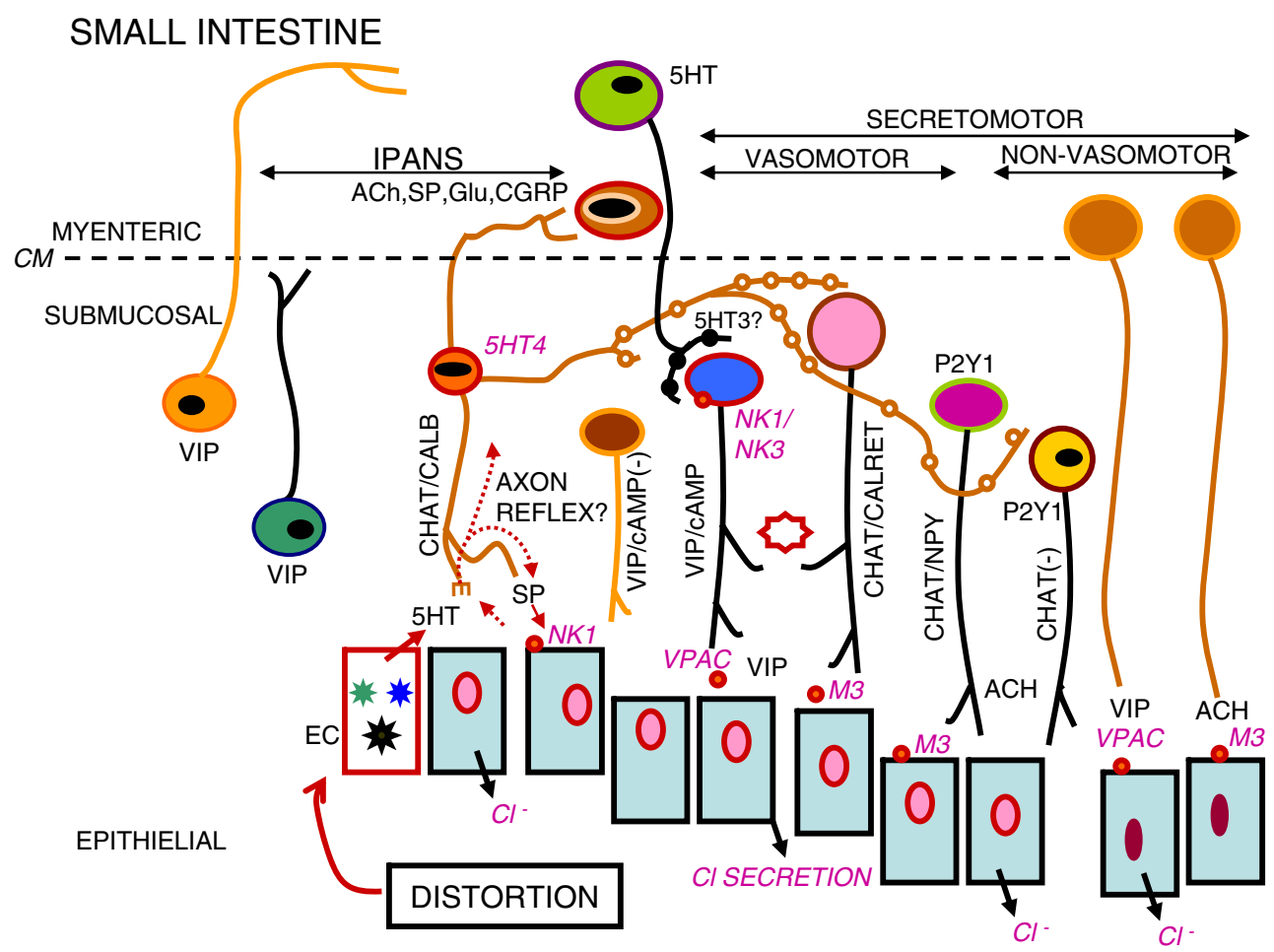

Fig. 1 Generic intestinal secretory reflex based on guinea pig intestine. Neural reflex pathway regulating secretion includes EC sensory cells that release 5-HT to activate IPANS projecting to the mucosa, to submucous ganglia, and to myenteric ganglia. IPANS synapse with several types of cholinergic (CHAT) and vasoactive intestinal peptide $(V I P)$ secretomotor neurons and release acetylcholine $(A C h)$ at muscarinic receptors (M3) and VIP at VIP receptors (VPACRs) on epithelial cells, or arterioles. VIP neurons are subdivided according to their ability to generate cAMP as VIP/cAMP (+) and VIP/

other mediators to trigger secretomotor reflexes leading to chloride, bicarbonate, potassium, mucin, and fluid secretion. EC cells communicate with both submucosal and myenteric IPANS to initiate secretomotor reflexes. Mucosal stimulation and activation of secretomotor reflexes via long myenteric pathways may play a role in the coordination of intestinal motility, secretion, and blood flow [88]. This review is restricted to submucous pathways and secretomotor reflexes. Under physiological circumstances, large fluctuations in secretions can occur depending on the stimulus. Crohn's disease or Clostridium difficile toxin A (TxA) can cause diarrhea and alterations in secretion. However, the diarrhea observed in IBD is mainly malabsorptive not secretory; in the inflamed gut, secretion actually decreases. Hypersecretion due to infection is helpful in flushing to rid the lumen of a pathogen.

Release of sensory mediators from EC cells activates the afferent nerve endings of IPANs to trigger a secretory reflex. IPANs detect sensory information from the luminal environment in the form of action potentials carried in their primary afferent process. The sensory information is
cAMP (-) and may be further subdivided into VIP/cAMP/A2aRs and $\mathrm{VIP} / \mathrm{cAMP} / \mathrm{A} 2 \mathrm{aR}(-)$. Cholinergic neurons are ChAT/calretinin (CALRET), CHAT/NPY, CHAT (-). Mechanical distortion such as brush stroking the mucosa is one stimulus for activation of the reflex. Myenteric secretomotor neurons project to the mucosa as well. CGRP calcitonin gene-related peptide, $E C$ enterochromaffin cells, 5-HT 5hydroxytryptamine, NK1 neurokinin-1, NPY neuropeptide Y, SP substance $\mathrm{P}, A 2 a R s$ adenosine $\mathrm{A}_{2 \mathrm{a}}$ receptors. (Modified from [25] by permission)

decoded and integrated in the cell soma and then relayed to interneurons or secretomotor neurons to elicit a secretory reflex. These IPANs in submucous ganglia have AH cell electrophysiological characteristics and comprise $15 \%$ of submucous neurons (and 25-30\% of myenteric neurons). The axonal processes of submucous IPANs are known to project to other IPANs and to submucous or myenteric neurons. They have Dogiel type II morphology and project in all directions in the submucous plexus [25].

One type of IPAN in the submucous plexus has one sensory process projecting to the mucosa and responds to mucosal distortion/deformation at sites less than $1 \mathrm{~mm}^{2}$ from the recording site. Another type of IPAN in the submucous plexus is sensitive to distention $[26,38,112]$. Notable differences exist in the chemical coding of these neurons in human, porcine, and rodent intestine [25]. After activation of IPANs, release of transmitters at synapses with interneurons or secretomotor neurons leads to epithelial secretion. 5-HT interplexus neurons send a process to synapse with secretomotor neurons expressing 5-HT3 receptors. Secretomotor neurons are S/type 1 neurons that 
release acetylcholine or VIP to activate the chloridesecreting crypt epithelial cells expressing muscarinic and VIP receptors. All cellular components of this reflex have functional adenosine (P1) or nucleotide (P2X and P2Y) receptor subtypes and are the subject of this review.

\section{Purinergic receptors}

Adenosine, adenosine 5'-triphosphate (ATP), ADP, AMP, uridine 5 '-triphosphate (UTP), UDP, and UDP-glucose are endogenous purines that activate $\mathrm{P} 1, \mathrm{P} 2 \mathrm{X}$, or $\mathrm{P} 2 \mathrm{Y}$ purinoceptor families that are widely and differentially distributed in the ENS and non-neuronal cells in the GI tract. The tissue distribution and/or biological experiments suggest that up to 14 of 18 purinoceptors may be involved in secretomotor reflexes in the GI tract. Still, our knowledge remains incomplete.

Adenosine interacts with four cell surface P1 receptors, designated as $A_{1}, A_{2 a}, A_{2 b}$, and $A_{3}$ receptors to influence a variety of physiological functions. The endogenous ligand is adenosine (or AMP, [41]). Receptor classification is based on receptor cloning, pharmacological studies, and mouse receptor knockout models. All four receptors are expressed in the GI tract, but their characterization is incomplete (see later). Adenosine receptors belong to the superfamily of seven transmembrane domain G protein-coupled receptors (GPCR) and they are emerging as potential therapeutic targets [53].

The nomenclature for the transmitter-gated ion channel $\mathrm{P} 2 \mathrm{X}_{1-7}$ receptors relies mostly on recombinant receptor pharmacology as reviewed by Khakh et al. [57]; the pharmacology of the P2X receptors in whole tissues is complicated by species differences, marked ectonucleotidase activity that interferes with agonist/antagonist potency profiles, and lack of very selective ligands for P2X receptor subtypes. Their review covers the functional properties of recombinant receptors, their pharmacology, ion effects $\left(\mathrm{Zn}^{2+}\right.$, $\left.\mathrm{H}^{+}, \mathrm{Ca}^{2+}\right)$, and some native receptors in tissues.

A recent review summarizes the pharmacological profiles of cloned mammalian metabotropic P2Y receptors [110] that have been shown to mediate actions of nucleotides when expressed in functional systems. Eight P2Y receptors have been cloned and defined functionally. The $\mathrm{P} 2 \mathrm{Y}_{1}, \mathrm{P} 2 \mathrm{Y}_{2}$, $\mathrm{P}_{2} \mathrm{Y}_{4}, \mathrm{P}_{2} \mathrm{Y}_{6}$, and $\mathrm{P} 2 \mathrm{Y}_{11}$ receptors are coupled to stimulation of phospholipase $\mathrm{C}$ (PLC). $\mathrm{P}_{2} \mathrm{Y}_{12}, \mathrm{P}_{2} \mathrm{Y}_{13}$, and $\mathrm{P} 2 \mathrm{Y}_{14}$ receptors are negatively coupled to adenylyl cyclase (AC); the $\mathrm{P} 2 \mathrm{Y}_{11}$ receptor is positively coupled to AC. Abbrachio et al. [1] provide an update on molecular mechanisms, pathophysiology, and therapeutics of P2Y receptors.

$\mathrm{P}_{2} \mathrm{Y}_{1}$ receptors are involved in platelet aggregation, vasodilation, neuromodulation, mechanosensitivity, and secretomotor reflexes. The $\mathrm{P} 2 \mathrm{Y}_{1}$ receptor is activated by ADP or its analog 2-methylthioADP (2MeSADP). A potent and selective antagonist is $2^{\prime}$-deoxy-N6-methyladenosine-3'5'-bisphosphate (MRS2179) or MRS2279. Adenosine 5'-O-(1-boranotriphosphate) (ATP- $\alpha$-B) derivatives are novel $\mathrm{P}_{2} \mathrm{Y}_{1}$ receptor agonists that may be of potential clinical relevance [78].

The $\mathrm{P} 2 \mathrm{Y}_{2}$ receptor plays an important role in $\mathrm{Cl}^{-}$secretion from epithelial cells, and a $\mathrm{P}_{2} \mathrm{Y}_{2}$ receptor agonist diquafosol is used for treatment of dry eye disease. It is activated by UTP and ATP and their actions are blocked by suramin, although suramin has affinity for non-purinergic receptors as well [54]. The $\mathrm{P}_{2} \mathrm{Y}_{4}$ receptor is expressed in epithelia, and depending on the species, the receptor has a strong preference for UTP (human receptor) or equal preference for UTP and ATP (rat receptor). Unlike the $\mathrm{P}_{2} \mathrm{Y}_{2}$ receptor it is not blocked by suramin. The $\mathrm{P}_{2} \mathrm{Y}_{6}$ receptor is distributed in the cardiovascular system and brain. It has a preference for UDP and 1,2-di-(4-isothiocyanatophenyl)ethane (MRS2567) is a selective antagonist. UDP also acts on receptors for cysteinyl leukotrienes. The $\mathrm{P}_{2} \mathrm{Y}_{11}$ receptor is blocked by suramin (and reactive blue 2) and it prefers ATP as an agonist. $\mathrm{P}_{2} \mathrm{Y}_{12}$ and $\mathrm{P} 2 \mathrm{Y}_{1}$ receptors are similar in that they are both activated by ADP and more potently by 2MeSADP. $\mathrm{P}^{2} \mathrm{Y}_{12}$ receptor antagonists are effective in clinical use to inhibit platelet aggregation; the receptor is also involved in inhibition of neuronal cells. Antagonists include N6-(2-methylthioethyl)-2-(3,3,3-trifluoropropylthio)$\beta \gamma$-dichloromethylene-ATP (AR-C6931MX or cangrelor), AZD6140, and active metabolites of clopidogrel and prasugrel. The $\mathrm{P} 2 \mathrm{Y}_{13}$ receptor is found in nerve cells and immunocytes and is activated similar to the $\mathrm{P} 2 \mathrm{Y}_{12}$ receptor, but is selectively blocked by 6-(2'-chloro-5-nitro-azophenyl)pyridoxal- $\alpha 5$-phosphate (MRS2211). The $\mathrm{P}_{2} \mathrm{Y}_{14}$ receptor is activated by UDP-glucose.

\section{Sensory enterochromaffin cells}

5-HT release from EC cells activates secretory, peristaltic, and vasomotor reflexes and contributes to the coordination of these reflexes. As shown in Fig. 2, EC cells with long basally located fine projections containing serotonin and sometimes connecting to neuron-like structures could be observed; other cells had short blunt processes or were dividing EC cells. A provocative possibility is the recent speculation that $\mathrm{EC}$ cells may even function as primary neurons [44].

EC cell dysfunction is implicated in malignant carcinoid, dumping, and irritable bowel syndromes, as well as IBD. 5HT secretion from carcinoid tumors is one of the putative mediators of carcinoid diarrhea that can be relieved by 5 -HT antagonists. 5-HT3 antagonists or a partial 5-HT4 agonist (i.e., tegaserod) are beneficial in treating diarrhea and constipation predominant symptoms in patients, respectively 


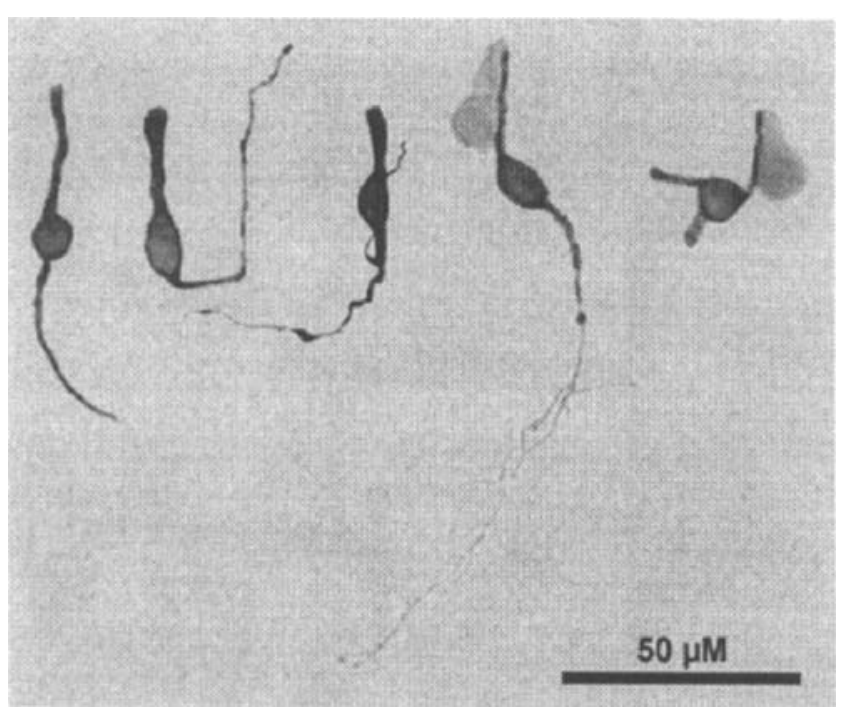

Fig. 2 Photomicrographs showing serotonin immunolabeled, formalinfixed EC cells dispersed from the colonic mucosa. All cells have luminal projections. From the left, four serotonin-positive cells with one or two basally located, axon-like projections are seen. The fourth of these cells connects with a neuron-like structure. Right: a cell with short and blunt basal projections. The EC cells are in some cases attached to neighboring mucosa cells. (Modified from [44] by permission)

[4, 67, 97]. Mucosal defects in 5-HT signaling occur in ulcerative colitis, diarrhea (or constipation) predominant IBS [24] or experimental colitis [67]. A better understanding of the signaling mechanisms, function, and dysfunction of EC cells is essential in understanding gut reflexes and symptoms of several diseases.

Despite the obvious importance of EC cells and 5-HT release in normal or disease states, our understanding of purinergic or other mechanisms involved in the regulation of 5-HT release is limited. Tissue studies are of limited use in helping us understand the complex regulation of 5-HT release because of potential interference from mediators released from neighboring cells. The human carcinoid BON cell line is a suitable EC cell model to study receptor and intracellular signaling pathways regulating 5-HT release [34].

A clone of BON/EC cells that is $99 \%$ enriched in 5-HT is a suitable $\mathrm{EC}$ model for population responses or for single cell functional studies. BON cells retain many of the mechanosensitive and chemosensitive properties of nontransformed cells, they respond to nutrients (glucose), mechanical activation (shaking, touch, stretch, volume changes, pressure), as well as receptor activation (purinergic, muscarinic, neurotensin, 5-HT, VIP, adrenergic, somatostatin, cholecystokinin, dopamine, bradykinin, etc.). A comparison of EC and BON cells indicates similarities in expression of receptors, ion transporters, ion channels, chemical mediators, or other mechanisms reviewed by Cooke and Christofi [25]. In addition to 5-HT, they secrete or contain adenosine, ATP neuron-specific enolase, synaptophysin, chromogranin A, neurotensin, vasoactive intestinal peptide (VIP), prostaglandins, and others. BON cell injection into nude mice can also serve as a model of carcinoid tumors [35].

\section{Chemosensitivity of $\mathrm{EC}$ cells}

EC cells have microvilli protruding into the lumen raising the possibility that they may "taste" the luminal contents. The nutrient monosaccharide D-glucose $(10-100 \mathrm{mM})$ or the nonmetabolizable $\alpha$-D-glucopyranoside (not fructose) caused a graded increase in 5-HT release in BON cells that was not caused by changes in osmolarity. Phloridzin blocked the effect of D-glucose by blocking D-glucose uptake [59, 87]. The role of purinergic modulation of nutrient activation of 5-HT release remains unknown.

\section{Mechanosensitivity of EC cells}

Mechanosensitivity in EC cells is poorly understood and the mechanosensitive elements remain unknown. Brush stroking, compression of the mucosa or villi, rotational stroking, or pressure/volume changes used to evoke mucosal secretomotor reflexes in the gut are not suitable to elicit 5-HT release in isolated EC/BON cells. Mechanical forces in the gut are complex and likely represent a composite of forces (pressure, shear force, centrifugal force, stretch, deformation, compression, touch, etc.). We succeeded in employing three different mechanical stimuli to elicit responses in EC cells to study purinergic regulation of mechanosensitive 5-HT release. Rotational shaking of cultured cells simulates forces that are generated in the intestinal lumen (i.e., shear forces, centrifugal forces, changes in hydrostatic pressure) and releases 5-HT. Pressures of $75 \mathrm{mmHg}$ or greater (normally associated with painful stimulation) applied to cells in a pressure chamber or laminar shear stress of $1-2 \mathrm{dyne} / \mathrm{cm}^{2}$ applied in a parallel plate flow chamber evoked 5-HT release [26].

\section{Second messengers in mechanosensitivity}

Balloon distension and puffs of nitrogen gas/pressure stimulate 5-HT release and trigger a reflex secretory response via submucous neurons in intact mucosa/submucosa preparations [84]. Rotational shaking of tissue preparations or the $\mathrm{EC} / \mathrm{BON}$ cells in culture predominantly activates a $\mathrm{G} \alpha \mathrm{q} / \mathrm{PLC} /$ inositol triphosphate $\left(\mathrm{IP}_{3}\right)-\mathrm{Ca}^{2+}$ signaling pathway leading to 5-HT release [59]. A separate $\mathrm{Gs} / \mathrm{Gi} / \mathrm{AC} /$ 
PKA (protein kinase A)/cAMP signaling pathway provides a minor contribution to mechanosensitive 5-HT release [18].

\section{Dual modulation of mechanosensitivity by $\mathrm{P}_{2} \mathrm{Y}_{1}$ and $\mathrm{P}_{2} \mathrm{Y}_{12}$ receptors}

Recent evidence from pharmacological and molecular studies support the hypothesis that dual modulation of 5HT release occurs via excitatory $\mathrm{P}_{2} \mathrm{Y}_{1}$ receptors coupled to the $\mathrm{G} \alpha \mathrm{q} / \mathrm{PLC} / \mathrm{IP}_{3}-\mathrm{Ca}^{2+}$ signaling pathway leading to 5-HT release [114] and inhibitory $\mathrm{P}_{2} \mathrm{Y}_{12}$ receptors coupled to $\mathrm{AC}$ (Christofi, Wunderlich, Xue, Cooke, unpublished observations; [120]). Touch/stretch evokes a $\mathrm{Ca}^{2+}$ response in $\mathrm{BON} / \mathrm{EC}$ cells that is used to study purinergic regulation of mechanosensitivity. In preliminary studies, touch $\mathrm{Ca}^{2+}$ responses in EC cells were inhibited by apyrase (ectonucleotidase) whereas a 5'-ectonucleotidase inhibitor ARL 67156 augmented responses indicating that a nucleotide is involved in mechanosensitivity. When single cells are examined and analyzed according to inhibition or augmentation of the $\mathrm{Ca}^{2+}$ response, dual modulation of the response is revealed in subsets of EC cells. Therefore, the $\mathrm{P} \mathrm{Y}_{1}$ receptor antagonist MRS2179 could either abolish the touch $\mathrm{Ca}^{2+}$ response or augment the response in different subsets of EC cells. MRS2179 could block touch-evoked $\mathrm{Ca}^{2+}$ responses in cells responsive to the $\mathrm{P}_{2} \mathrm{Y}_{1}$ receptor agonist 2MeSADP. The $\mathrm{Ca}^{2+}$ response evoked by 2MeSADP was either inhibited or augmented by MRS2179 in subsets of EC cells; an additional component of the touch $\mathrm{Ca}^{2+}$ response was blocked by the $\mathrm{P} 2$ receptor antagonist PPADS [114].

In molecular signaling studies, when the human $\mathrm{P}_{2} \mathrm{Y}_{1}$ receptor was overexpressed in $\mathrm{BON}$ cells with naitive $\mathrm{P} 2 \mathrm{Y}$ receptors, it caused additional mobilization of $\mathrm{Ca}^{2+}$ in the cells and augmented 5-HT release. A $\mathrm{P}_{2} \mathrm{Y}_{1}$ receptor silencing RNA reduced receptor expression leading to a reduction in 5-HT release. In heterologous $1321 \mathrm{~N} 1$ cells, transfection of human $\mathrm{P}_{2} \mathrm{Y}_{1}$ receptors enabled the cells to generate a $\mathrm{Ca}^{2+}$ response to mechanical stimulation. $\mathrm{P}_{2} \mathrm{Y}_{1}$ receptor antagonists MRS2179 or A3P5P abolished the $\mathrm{Ca}^{2+}$ response in $1321 \mathrm{~N} 1$ cells or 5-HT response in BON cells that overexpressed the human $\mathrm{P}_{2} \mathrm{Y}_{1}$ receptor [120]. Overexpression of the $\mathrm{P}_{2} \mathrm{Y}_{12}$ receptor in $\mathrm{BON}$ cells and/or HEK293 cells nearly abolished mechanically evoked 5-HT release (BON) and cAMP (both cell types). Blockade of $\mathrm{P} \mathrm{Y}_{12}$ receptors by 2-MeSAMP augmented the cAMP responses. 5-HT release was augmented after knockdown of $\mathrm{P} 2 \mathrm{Y}_{12}$ receptors in $\mathrm{BON}$ cells; silencing of $\mathrm{P}_{2} \mathrm{Y}_{13}$ receptors had no effect. Therefore, molecular studies are consistent with pharmacological studies and suggest that dual purinergic modulation of mechanosensory signaling via
$\mathrm{P}_{2} \mathrm{Y}_{1}$ and $\mathrm{P}_{2} \mathrm{Y}_{12}$ receptors (that recognize both MRS2179 and 2MeSADP) leads to 5-HT release in EC cells. The P2 $\mathrm{Y}_{1}$ and $\mathrm{P} 2 \mathrm{Y}_{12}$ receptors may provide new targets for modulation of mucosal secretory reflexes and are potential therapeutic targets, as shown for platelets [1]. The role of other receptors expressed in $\mathrm{EC} / \mathrm{BON}$ remains unknown. Messenger RNA transcripts for $\mathrm{P}_{2} \mathrm{Y}_{1}, \mathrm{P}_{2} \mathrm{Y}_{2}, \mathrm{P}_{2} \mathrm{Y}_{4}, \mathrm{P} 2 \mathrm{Y}_{6}$, $\mathrm{P}_{2} \mathrm{Y}_{11}, \mathrm{P}_{2} \mathrm{Y}_{12}$, and $\mathrm{P} 2 \mathrm{Y}_{13}$ exist in BON cells $[25,26]$.

\section{Adenosinergic modulation of 5-HT release}

Endogenous adenosine modulates the basal release of 5-HT from EC/BON cells. Adenosine deaminase caused a dosedependent increase in 5-HT release (Fig. 3a). The nucleoside uptake inhibitor $S$-(p-nitrobenzyl)-6-thioinosine (NBTI) prevented mechanically evoked 5-HT release (Fig. 3b) by elevating endogenous adenosine (Fig. 3c). Overall, endogenous adenosine is sufficient to provide ongoing inhibition of basal and mechanically evoked 5-HT release. The adenosine $\mathrm{A}_{3}$ receptor is activated by endogenous adenosine since baseline 5-HT release was augmented by an $\mathrm{A}_{3}$ receptor antagonist MRS1191 and this was sensitive to an $\mathrm{A}_{3}$ receptor agonist IB-MECA (Fig. 3d); the $\mathrm{A}_{3}$ effect was restricted to the $\mathrm{Ca}^{2+}$ signaling pathway. The $\mathrm{A}_{1}$ receptor also contributes, and an $\mathrm{A}_{1}$ receptor antagonist (CPT), an $\mathrm{A}_{3}$ receptor antagonist (MRS1191), or adenosine deaminase could also augment the touch/stretch $\mathrm{Ca}^{2+}$ response (Fig. 3e). Touch $\mathrm{Ca}^{2+}$ responses occur via a $\mathrm{G} \alpha \mathrm{q} / \mathrm{PLC} / \mathrm{IP}_{3}$ pathway that is the predominant mechanism in 5-HT release from EC cells. $5^{\prime}-\mathrm{N}$ methylcarboxy aminoadenosine (MECA) elevated both 5-HT and cAMP levels in BON cells. $\mathrm{A}_{2}$ receptor antagonists could suppress mechanically evoked 5 -HT release indicating the endogenous adenosine can contribute to stimulation of 5-HT release via $\mathrm{A}_{2}$ receptors. Together, these and other findings indicate that endogenous adenosine can activate inhibitory $\mathrm{A}_{3} /$ $\mathrm{A}_{1}$ receptor- $\mathrm{G} \alpha \mathrm{q} / \mathrm{PLC} / \mathrm{IP}_{3}-\mathrm{Ca}^{2+}$ and excitatory $\mathrm{A}_{2 \mathrm{a}} / \mathrm{A}_{2 \mathrm{~b}}$ receptor-AC/cAMP signaling pathways on $\mathrm{EC}$ cells to regulate 5-HT release; $A_{1}, A_{2 a}, A_{2 b}$, and $A_{3}$ receptors or mRNA transcripts are present in both $\mathrm{BON} / \mathrm{EC}$ cells, gastric and intestinal 5-HT-ir carcinoid tumors [18]. Recent isolation of ileal EC cells [58] may permit further study and comparison of purinergic signaling mechanisms in normal and diseased human ileum. Real-time electrochemical detection of local mucosal 5-HT release is also very promising [5].

\section{Intestinal secretory reflexes}

Hubel's [51] pioneering spirit and studies demonstrated that electrical field stimulation of tissue setup in Ussing chambers can stimulate transepithelial short-circuit current (Isc) changes indicative of ion transport. His studies 

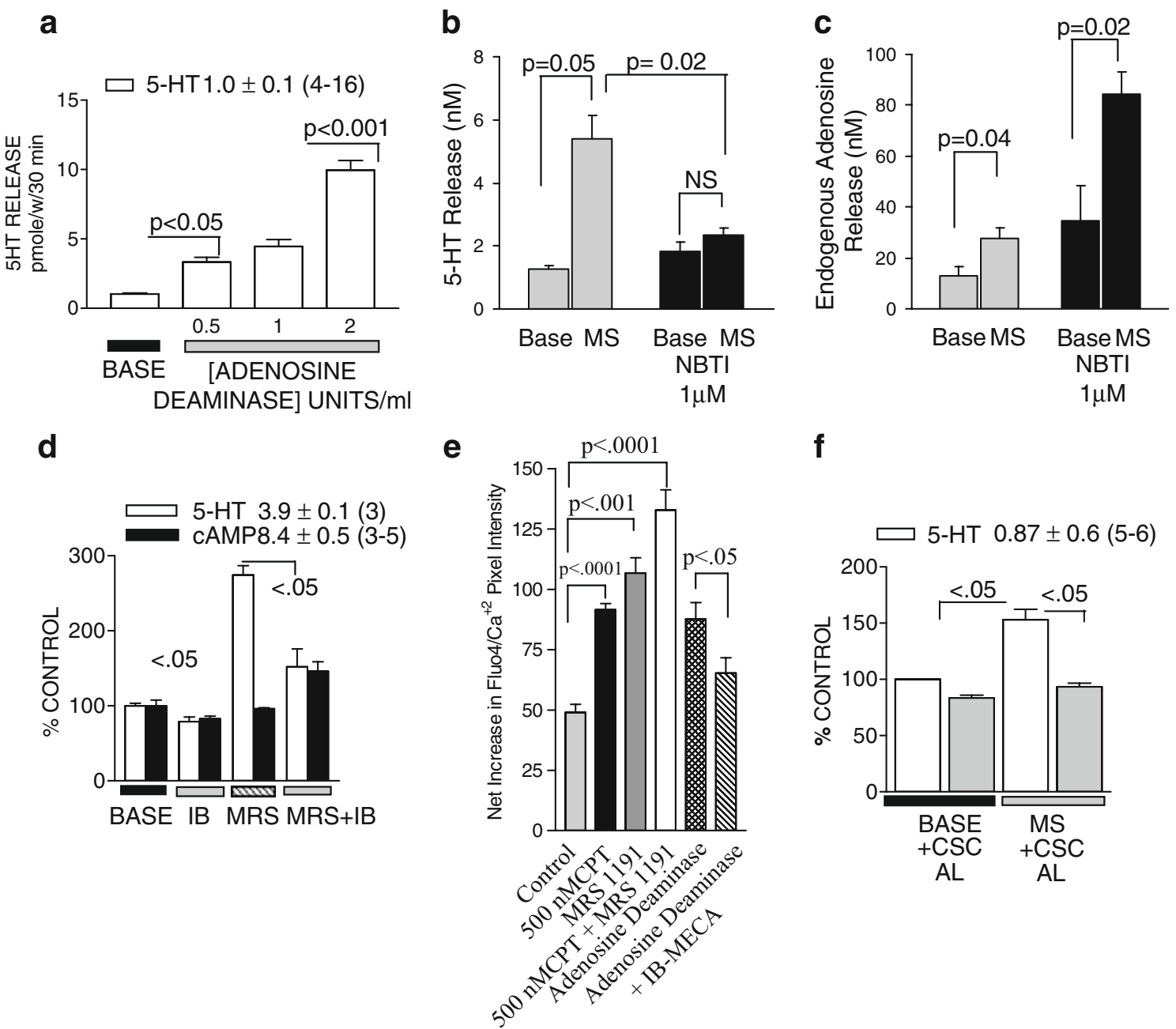

f

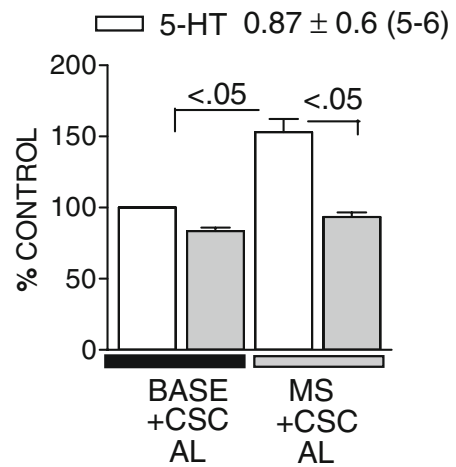

Fig. 3 Regulation of 5-hydroxytryptamine (5-HT) release by endogenous adenosine release from $\mathrm{BON}$ cells via inhibitory $\mathrm{A}_{1} / \mathrm{A}_{3}$ receptors and excitatory $A_{2}$ receptors. a The enzyme ADA caused a dose-dependent increase in 5-HT release, indicating that release of endogenous adenosine provides an ongoing inhibition of 5-HT release. b In the same cells as a, NBTI blocked adenosine uptake and abolished mechanically evoked 5-HT release. c Adenosine release during resting/unstimulated conditions (Base) and mechanical stimulation $(M S)$ is augmented in the presence of the adenosine uptake inhibitor $S$-(p-nitrobenzyl)-6-thio-inosine (1 $\mu \mathrm{M}$ NBTI). d Chemical stimulation with IB-MECA decreased basal 5-HT and the $\mathrm{A}_{3} \mathrm{R}$ agonist cAMP levels. The $\mathrm{A}_{3} \mathrm{R}$ antagonist MRS1191 (10 nM) augmented 5HT release but not cAMP levels $(p<0.05)$. The MRS1191-evoked 5$\mathrm{HT}$ response was sensitive to IB-MECA inhibition. e Adenosine $A_{1}$

provided proof that submucous neurons could regulate chloride secretion. This sparked the beginning of a new era of investigation on the influence of the ENS on epithelial secretion and secretomotor reflexes.

The secretory reflex can be activated by nutrients or mechanical stimulation or exposing the gut to food antigens regarded as foreign or to enteropathogenic microorganisms. The mucosal surveillance and immune defense system is exposed to an estimated $10^{12}$ different antigens per day that mobilizes both intrinsic and extrinsic nervous systems, and $\mathrm{A}_{3} \mathrm{R}$ inhibitory components of touch-evoked $\mathrm{Ca}^{2+}$ responses in enterochromaffin/BON cells. The $\mathrm{A}_{3} \mathrm{R}$ antagonist MRS1191 augmented the touch $\mathrm{Ca}^{2+}$ transient. Chronic exposure to the $\mathrm{A}_{1}$ antagonist CPT for $24 \mathrm{~h}$ caused a significant augmentation in the touch $\mathrm{Ca}^{2+}$ response. The stimulatory effects of CPT and MRS1191 were additive on the touch $\mathrm{Ca}^{2+}$ response. Adenosine deaminase ( 5 units/ml)-induced augmentation is reduced by the $\mathrm{A}_{3} \mathrm{R}$ agonist IBMECA $(50 \mathrm{nM})$. f $\mathrm{A}_{2 \mathrm{~A}} / \mathrm{A}_{2 \mathrm{~B}}$ antagonists CGS and $\mathrm{AL}$ (alloxazine) inhibited mechanically evoked 5-HT release. Baseline values (pmol/ well per $30 \mathrm{~min}$ ) of 5-HT and/or cAMP are at the top of figures with the number of experiments indicated in parentheses. IB IB-MECA, MRS MRS1191, ME MECA, $A L$ alloxazine, CGS CGS 21680, MS mechanical stimulation by rotational shaking at $80 \mathrm{rpm}, N S$ not significant. (Modified from [59] by permission)

hormones, paracrine substances, and immune mediators to modulate chloride secretory rates.

The net flux of ions into the gut lumen is the balance of secretion and absorption. Basal secretion or "secretory tone" is also the net flux of ions and fluid into the intestinal lumen that is dependent on the spontaneous release of endogenous paracrine, autocrine, or neurocrine mediators. Secretory tone is assessed from changes in basal Isc, a measure of chloride secretion. The basal Isc is under ongoing neural stimulation. Data with P2 receptor antago- 
nists (PPADS, suramin) or P1 receptor antagonists (CPT), nucleotidases, or nucleotidase inhibitors indicated that endogenous nucleotides stimulate, while endogenous adenosine inhibits basal Isc [29]. However, basal secretion is not affected by $\mathrm{P} 2 \mathrm{X}$ or $\mathrm{P} 2 \mathrm{Y}_{1}$ receptors because neither of NF279 or MRS2179 influenced Isc. Overall, adenosine, nucleotides, somatostatin, and prostaglandins all contribute to "secretory tone" $[26,27]$.

\section{$\mathrm{P}_{1} \mathrm{Y}_{1}$ receptors and mucosal stroking-evoked neurosecretory reflexes in the colon}

Mechanical or chemical activation of the mucosa can lead to an intestinal neural reflex and an increase in ion transport and fluid secretion. Very few studies have investigated purinergic regulation of secretomotor function [18, 27-29]. Mucosal distortion by brush stroking or distension can elicit the reflex (Fig. 4).

Brush stroking of the mucosa causes an intestinal neural reflex response and an increase in Isc indicative of electrogenic chloride ion transport. The brush stroking reflex in the rat colon mucosa-submucosa is reduced by MRS2179 or apyrase and further inhibited by tetrodotoxin (TTX). 2MeSADP, a mixed $\mathrm{P}_{2} \mathrm{Y}_{2} / \mathrm{P}_{2} \mathrm{Y}_{4}$ agonist UTP, or ATP (P2 receptor agonist) evoked neural and non-neural secretory responses. Mucosal touch/distension evoked fluo- $4 / \mathrm{Ca}^{2+}$ responses in submucous neurons were also inhibited by apyrase or blocked completely by MRS2179 (Fig. 5); MRS2179 only reduced Isc in stroking reflexes. The potency profile of nucleotides for reducing Isc is different from that for touch $\mathrm{Ca}^{2+}$ responses [18]. $\mathrm{P} 2 \mathrm{Y}_{1}$ immunoreactivity was identified in a majority of VIP, NOS, calretinin, NPY, or somatostatin neurons but not SP or calbindin submucous neurons. $\mathrm{P}_{2} \mathrm{Y}_{4}$ immunoreactivity occurred mainly in the cell somas of NPY neurons (93\%). P2 $\mathrm{Y}_{2}$ immunoreactivity occurred in a minority of SP, VIP, NPY CGRP varicose fibers $(5-20 \%)$ and those surrounding calbindin neurons $[18$, 26]. Purinergic responses could be distinguished based on stroking reflexes, touch-evoked $\mathrm{Ca}^{2+}$ reflexes, actions of nucleotides, or sensitivity to antagonists. These and other data suggest that several nucleotides may contribute to mechanically evoked secretomotor reflexes. Nucleotides differentially activate $\mathrm{P} 2 \mathrm{Y}_{1}, \mathrm{P}_{2} \mathrm{Y}_{2}$, and $\mathrm{P}_{2} \mathrm{Y}_{4}$ receptors located at putative pre- or postsynaptic sites on submucous neurons. In rat hippocampus, ATP may activate presynaptic

\section{a Mucosal Stroking - Forward Stroke}

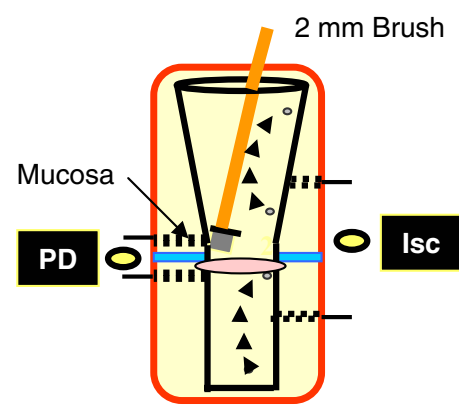

\section{b Mucosal Stroking - $360^{\circ}$ Rotation of Brush}

\section{Isc}

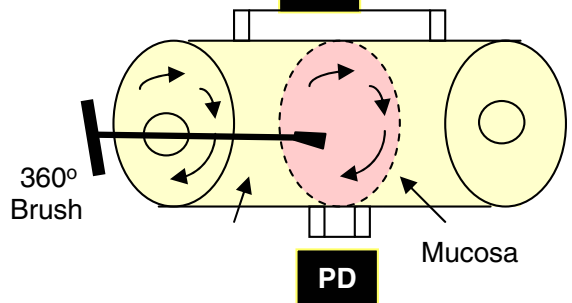

C Dissention - Fluid Removal

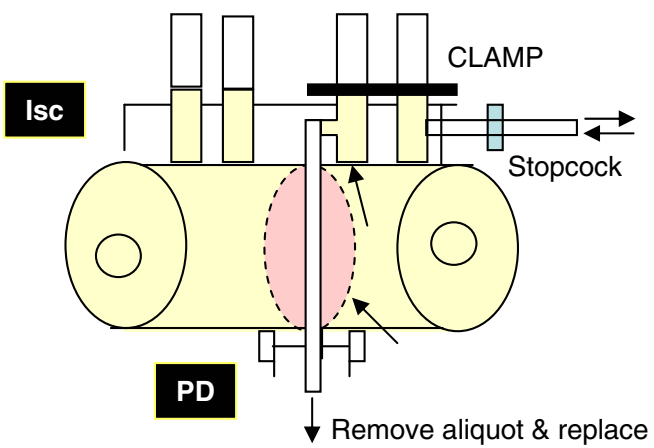

Fig. 4 Modified Ussing chambers used for mucosal stroking studies to evoke a reflex neurosecretory response. a Vertical configuration of the chamber permits a $2-\mathrm{mm}$ brush to be placed on the mucosal surface. A single stroke represents the directional movement of the brush from one side to the other on the surface of the mucosa. b A complete $360^{\circ}$ turn of the brush is another variation for stimulating reflexes; stroke (1 s) is reproducible every $5 \mathrm{~min}$ for a 40 -min period. c

Distention is accomplished by removing small volumes of fluid from the serosal side. Drugs are perfused separately on the serosal or mucosal surfaces of the mucosa-submucosa or whole thickness colonic or small bowel tissues. The Isc/short-circuit current nulled out the spontaneous potential difference $(P D)$ and was used as a measure of chloride secretion in the distal colon. (Modified from [25] by permission) 
$\mathrm{P}_{2} \mathrm{Y}_{1}, \mathrm{P}_{2} \mathrm{Y}_{2}$, and $\mathrm{P} 2 \mathrm{Y}_{4}$ receptors to inhibit glutamate release [91]; presynaptic $\mathrm{P}_{2} \mathrm{Y}_{1}$ and $\mathrm{P} 2 \mathrm{Y}_{2}$ receptors also occur in the rat submucous plexus. A working model of the purinergic neural circuitry in the rat colon is shown in Fig. 6.

ARL 67156 augmented, whereas apyrase, atropine, or TTX could inhibit stroking-evoked reflex Isc responses in guinea pig distal colon (Fig. 7a). The agonist potency profile of 2MeSADP $>$ UTP $\geq$ UDP for stimulation of neural secretion supports a $\mathrm{P}_{2} \mathrm{Y}_{1}$ receptor (Fig. $7 \mathrm{~b}$ ), but does not exclude others. MRS2179 reduced the stroking response by $54 \%$ and the effect of $2 \mathrm{MeSADP}$ by $70 \%$. P2 receptor antagonists PPADS and suramin had additive inhibitory effects. The $\mathrm{P} 2 \mathrm{X}_{1 / 3}$ receptor agonist $\alpha \beta$ MeATP caused stimulation of Isc, and a desensitizing concentration reduced stroking-evoked secretion but did not affect the 2MeSADP response. Cell bodies of guinea pig colonic submucous neurons expressed P2Y immunoreactivity. About $20-50 \%$ of submucous neurons expressed $\mathrm{P}_{2} \mathrm{Y}_{1}$ and $\mathrm{P}_{2} \mathrm{Y}_{2}$ receptors. $\mathrm{P} 2 \mathrm{Y}$ immunoreactivity $\left(\mathrm{P} 2 \mathrm{Y}_{1}, \mathrm{P} 2 \mathrm{Y}_{2}\right.$, or $\mathrm{P}_{2} \mathrm{Y}_{4}$ ) was virtually undetectable in any varicose fibers. $\mathrm{P} 2 \mathrm{Y}_{1}$ immunoreactivity was abundant in putative cholinergic secretomotor neurons and fewer than $2 \%$ of NPY/cholinergic secretomotor neurons [71]. In contrast, $\mathrm{P}_{2} \mathrm{Y}_{2}$ immunoreactivity was found in all NPY secretomotor neurons and $30 \%$ of calbindin/intrinsic sensory neurons. $\mathrm{P}^{2} \mathrm{Y}_{4}$ is of minor significance in submucous neurons. In guinea pig, mucosal stroking may activate putative $\mathrm{P} 2 \mathrm{X}_{1 / 3}$, $\mathrm{P}_{2} \mathrm{Y}_{1}$, and $\mathrm{P} 2 \mathrm{Y}_{2}$ receptors located at postsynaptic membranes of submucous neurons leading to chloride secretion; $\mathrm{P}_{2} \mathrm{Y}_{1}$ receptors on $\mathrm{EC}$ also contribute. Based on the available evidence, it was hypothesized that a separate $\mathrm{P}_{2} \mathrm{Y}_{2}$ neural circuit pathway exists in guinea pig that is not activated by stroking the mucosa $[25,27]$. In both rat and guinea pig, receptors or mRNA transcripts exist for $\mathrm{P}_{2} \mathrm{Y}_{1}$, $\mathrm{P}_{2} \mathrm{Y}_{2}, \mathrm{P}_{2} \mathrm{Y}_{4}, \mathrm{P}_{2} \mathrm{Y}_{6}$, and $\mathrm{P} 2 \mathrm{Y}_{12}$ receptors in the submucosa, and therefore influence of other receptors in stroking reflexes deserves further attention. Species differences exist between mucosal stroking reflexes in rat [18] and guinea pig [27] distal colon in purinergic regulation, and no information exists for the human GI tract.

\section{Neurogenic mucosal secretion and $\mathrm{P}_{2} \mathrm{Y}_{1}$ receptors in small intestine}

In the guinea pig small intestine, it was shown that neurogenic mucosal secretion is mediated by the $\mathrm{P} 2 \mathrm{Y}_{1}$ receptor that may be expressed on VIP secretomotor neurons. MRS2179 blocked the neurally mediated ATPevoked response with an $\mathrm{IC}_{50}$ of $0.9 \mu \mathrm{M}$. TTX could suppress or abolish the ATP response. The $\mathrm{P}_{2} \mathrm{Y}_{1}$ receptor was coupled to $\mathrm{PLC} / \mathrm{IP}_{3} / \mathrm{Ca}^{2+}$-calmodulin/protein kinase $\mathrm{C}$ signaling pathway [37] like that on EC/BON cells.
Fig. 5 Laser confocal imaging of touch-induced purinergic $\mathrm{Ca}^{2+}$ signals in neurons of the intact microdissected submucous plexus of the rat distal colon. a Perfusion chamber used to record touch-induced $\mathrm{Ca}^{2+}$ responses in the neurons. It includes a recording chamber made of a $35-\mathrm{mm}$ microwell dish with a $1-\mathrm{cm}$, number 0.0 cover glass in the center of the bottom of the dish for visualizing the fluorescent neurons. A portion of the dish is embedded with a $2-\mathrm{mm}$ thick layer of Sylgard shaped around a half moon at one end of the dish. Perfusion with oxygenated buffer or drugs is exactly opposite to the suction. The microdissected M-SMP preparation is stretched and fixed with many (15-20) micropins along the Sylgard layer. The remaining SMP without mucosa is stretched over the glass cover slip of the dish and secured with magnetic metal feet (not shown). A large ganglion of the intermediate layer of the submucous plexus is viewed with a $40 \times$ oil immersion objective (N.A. 1.3). b Inset shows Fluo-4/AM loaded neurons representing second order neurons that are visualized. c Side view of the tissue: The submucous plexus layer is located flat on the bottom of the dish and the mucosa/submucosa lifts over the Sylgard ends at each side of the half moon. The tissue is touched for $20 \mathrm{~s}$ on the mucosal surface of M-SMP portion that is stretched across the Sylgard with a fire-polished glass pipette to evoke $\mathrm{a} \mathrm{Ca}^{2+}$ response in the neurons - the tissue is free to move/stretch downward during the touch, since it is located a distance of $2 \mathrm{~mm}$ above the glass bottom. d-g The $\mathrm{P}_{2} \mathrm{Y}_{1}$ antagonist MRS2179 or TTX abolish the touchinduced $\mathrm{Ca}^{2+}$ fluorescence response. A representative example of the effects of MRS2179 and TTX on touch-induced $\mathrm{Ca}^{2+}$ transients in a single ganglion (seven neurons in one ganglion). A 20-min exposure to the selective $\mathrm{P}_{2} \mathrm{Y}_{1}$ antagonist MRS2179 $(10 \mu \mathrm{M})$ abolished the touch response in the neurons. In the presence of $0.2 \mu \mathrm{M}$ TTX, the touch response decreased to below baseline levels. Arrows indicate touch-responsive cells. $\mathbf{h}$ Pooled data for the peak effects of MRS2179 and TTX; averaged transients from 30 neurons from 3 to 4 separate ganglia. i Breaking down endogenous nucleotides reduces the touch-induced $\mathrm{Ca}^{2+}$ response in the neurons of the intact M-SMP. The touch response was determined in the presence of 5 units $/ \mathrm{ml}$ apyrase exposed for $10 \mathrm{~min}$. Apyrase reduced by $50 \%$ the control touch response $(n=4$ neurons, $p<0.01)$. Values are means \pm SEM. (Modified from [18] by permission)

\section{Purinergic modulation of local inhibitory reflexes}

Local inhibitory reflexes to the circular muscle evoked by mucosal application of nutrient amino acids in guinea pig jejunum are partially blocked by antagonists to P2X receptors suggesting involvement of ATP [46]. The receptor subtype(s) have not been characterized. Effects of nutrients on local secretomotor reflexes and involvement of purinergic signaling in the coordination of motility and secretion remain unclear, although some data are emerging on adenosine $A_{3}$ and $\mathrm{A}_{1}$ inhibitory receptors (see later section on "Neurogenic diarrhea"; $[8,9])$.

Fluo- $4 / \mathrm{Ca}^{2+}$ imaging studies are providing new insights into the functional purine receptors involved in the excitability and synaptic transmission in intact neural circuits of the submucous plexus of the human gut. A recent study indicated that the submucous plexus from Roux-en-Y patients is a suitable model to study synaptic transmission in the human enteric nervous system [115]. It was shown that the $\mathrm{P} 2 \mathrm{Y}_{1} \mathrm{G} \alpha \mathrm{q}-\mathrm{PLC} / \mathrm{IP}_{3} \mathrm{Ca}^{2+}$ signaling 

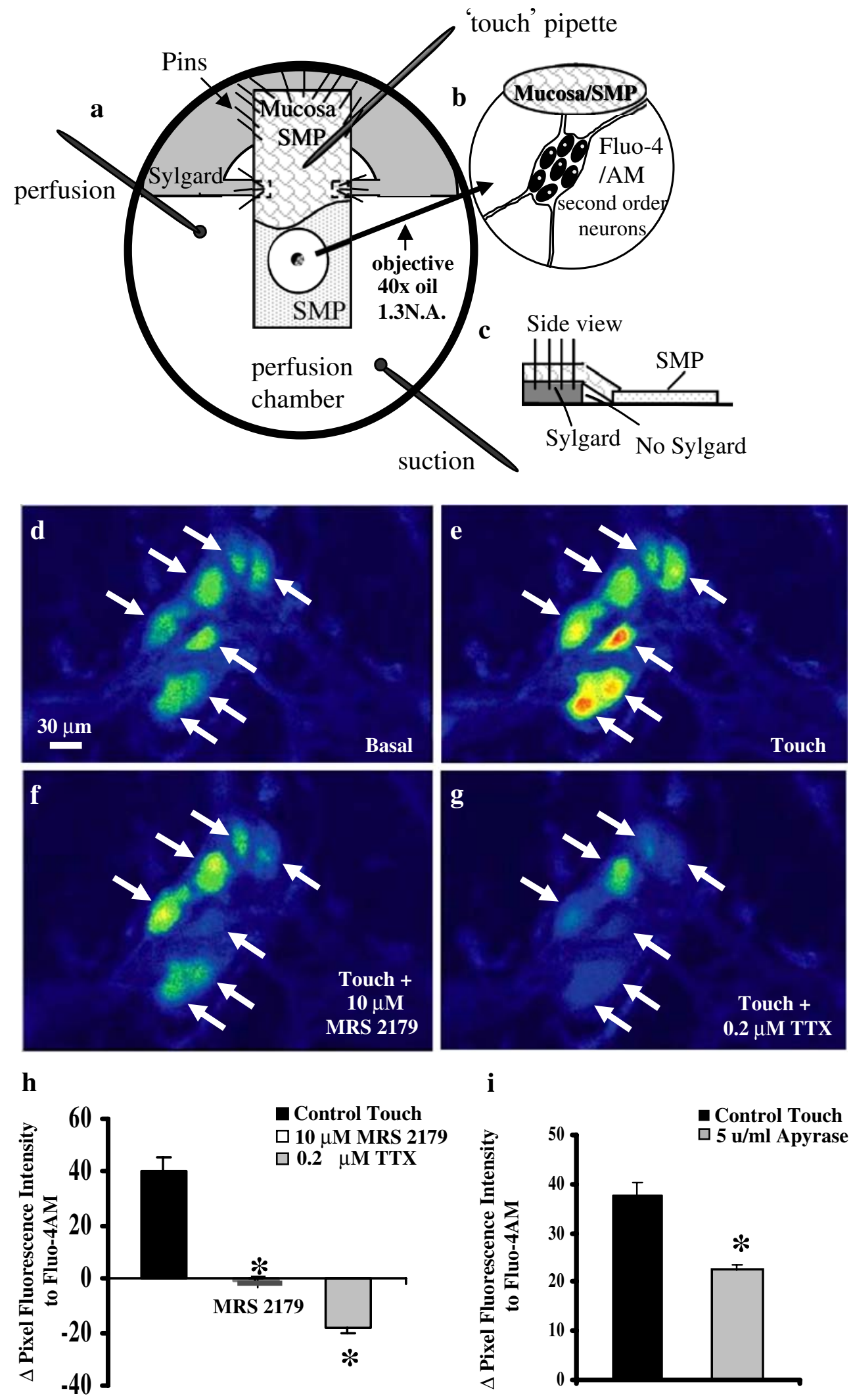
Mechanical Activation of Purinergic Neural Circuitry in Rat Distal Colon

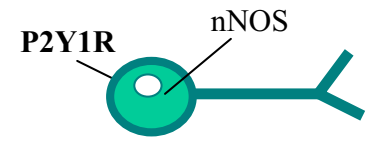

VIP

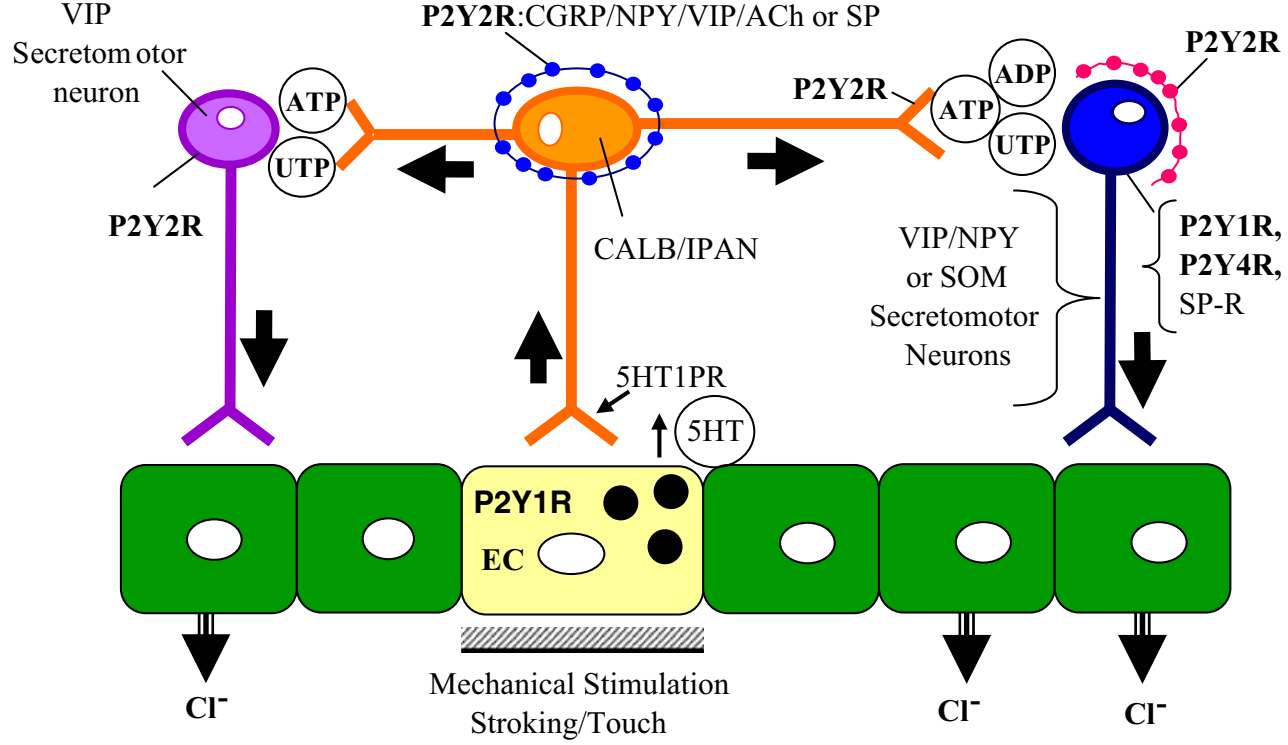

Fig. 6 Mechanical activation of purinergic neural circuitry in rat distal colon. Mucosal brush stroking or touch/stretch releases nucleotides that may include ATP, UTP, and ADP that activate neural P2 $\mathrm{Y}_{1}, \mathrm{P}_{2} \mathrm{Y}_{2}$, and $\mathrm{P}_{2} \mathrm{Y}_{4} \mathrm{Rs}$ at pre- or postsynaptic sites of submucous neurons leading to a net increase in Isc/chloride secretion. Intrinsic primary afferent neurons do not express P2YRs on their cell somas, but receive strong synaptic inputs from extrinsic fibers (i.e., pelvic origin) with $\mathrm{P} 2 \mathrm{Y}_{2} \mathrm{Rs}$ forming baskets of varicose fibers surrounding their cell somas. A very tiny subset of VIP secretomotor neurons expresses $\mathrm{P} 2 \mathrm{Y}_{2} \mathrm{R}$. P2 $\mathrm{Y}_{2} \mathrm{Rs}, \mathrm{P} 2 \mathrm{Y}_{1} \mathrm{Rs}$, and $\mathrm{P} 2 \mathrm{Y}_{4} \mathrm{Rs}$ are coexpressed on $>90 \%$ of

pathway, $\mathrm{N}-\mathrm{Ca}^{2+}$ channels, nicotinic receptors, and extrinsic nerves are involved in neurotransmission. Pharmacological findings suggest that inhibitory adenosine $\mathrm{A}_{3}$ receptors modulate nucleotide and cholinergic transmission in the human enteric nervous system.

In the guinea pig small intestine, electrophysiological studies revealed that AMP activates presynaptic inhibitory $A_{1}$ receptors to suppress neurotransmission and postsynaptic $A_{2 a}$ receptors to elicit a slow excitatory postsynaptic potential (EPSP)-like response. Signaling pathways coupled to $\mathrm{A}_{2 \mathrm{a}}$ receptors include $\mathrm{AC}, \mathrm{PLC}, \mathrm{PKC}$, and calmodulindependent kinases [41]; whether AMP can also activate $\mathrm{A}_{2 \mathrm{~b}}$ or $\mathrm{A}_{3}$ receptors remains unclear.

\section{Endogenous adenosine and $A_{1}$ receptors in mucosal reflexes}

The role of endogenous adenosine in the physiological regulation of mucosal secretory reflexes was investigated in pharmacological studies [29]. At nanomolar concen-

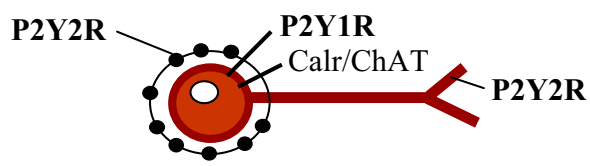

P2Y2R

NPY/VIP putative secretomotor neurons that also express SP Rs. $\mathrm{P} 2 \mathrm{Y}_{1}$ Rs are also expressed on putative somatostatin (SOM) neurons. Activation of $\mathrm{P}_{2} \mathrm{Y}_{1}$ Rs leads to a rise in intracellular free $\mathrm{Ca}^{2+}$ levels in the secretomotor neurons by ATP, UTP, or ADP. A nicotinic cholinergic synapse has not been ruled out. NOS neurons and CALR/CHAT cholinergic neurons also express $\mathrm{P}_{2} \mathrm{Y}_{1} \mathrm{Rs}$, but the functional role of these subsets of neurons is unknown. $\mathrm{P} 2 \mathrm{Y}_{2} \mathrm{Rs}$ are discretely localized on some extrinsic fibers of SP, VIP, NPY, CGRP, or cholinergic origin presumed to be involved in synaptic modulation of transmitter release. (Modified from [18] by permission)

trations, the $\mathrm{A}_{1}$ antagonist 8-chlorophenyltheophylline (CPT) caused a concentration-dependent enhancement of the stroking reflex. The effect still occurred in the presence of an $\mathrm{A}_{2 \mathrm{a}}$ receptor antagonist 8-(3-chlorostyrl) caffeine. Adenosine deaminase $(5 \mathrm{U} / \mathrm{ml})$ also enhanced the reflex secretory response, whereas the nucleoside uptake blocker NBTI inhibited it. The $\mathrm{A}_{1}$ receptor agonist 2-chloro-N6cyclopentyladenosine (CCPA) inhibited reflex-evoked Isc (Fig. $8 \mathrm{a} ; \mathrm{EC}_{50}=6 \mathrm{nM}$ ) and its effect was also blocked by CPT. In experiments with either piroxicam to block the prostaglandin (PG)-mediated pathway or $N$-acetyl-5hydroxytryptophyl-5-hydroxytryptophan amide to block the 5-HT mediated pathway, CCPA reduced or abolished the residual reflex Isc response (Fig. 8b). CCPA could abolish the reflex response to a pulse of 5-HT (Fig. 8c) without affecting TTX-insensitive epithelial responses to carbachol or forskolin. $A_{1}$ immunoreactivity was expressed in submucous neurons, in presynaptic varicose nerve endings (synaptophysin-positive neurons), and in glia. The chemical coding of those submucous neurons is not known. Overall, available data suggest that endogenous adenosine 

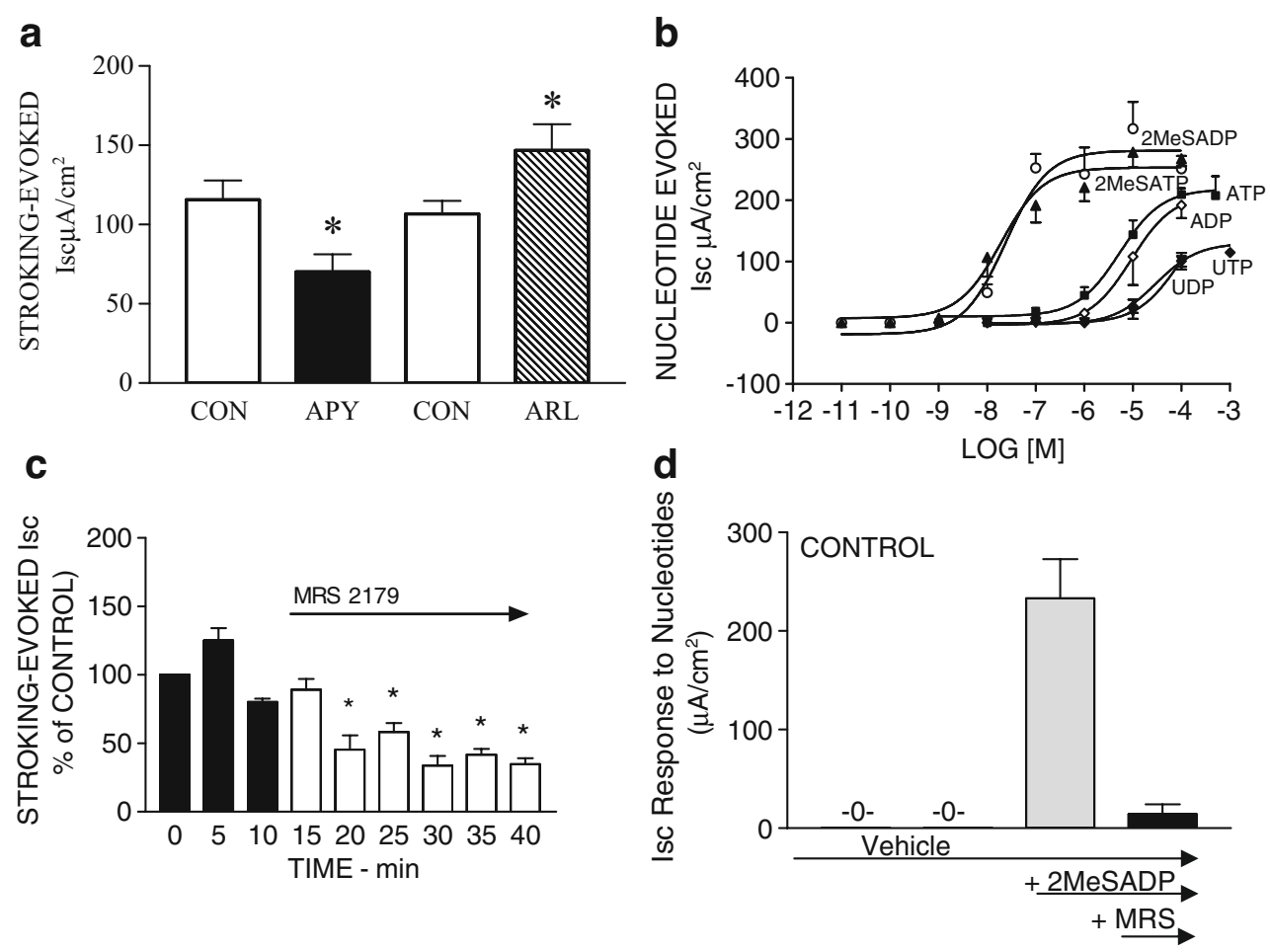

Fig. 7 Mucosal stroking releases endogenous ATP/nucleotides that activate excitatory neural $\mathrm{P} 2 \mathrm{Y}_{1}$ Rs leading to an increase in Isc/chloride secretion in the guinea pig colon. a The ATPase $/ 5^{\prime}$-nucleotidase inhibitor 6- $N, N$-diethyl- $\beta, \gamma$-dibromomethylene-D-adenosine-5'-triphosphate trisodium (10 $\mu \mathrm{M}$, ARL 67156 or ARL) prevents hydrolysis of ATP and enhanced reflex-evoked Isc $(n=6, * p<0.05)$, whereas $10 \mathrm{U} / \mathrm{ml}$ apyrase hydrolyzes ATP and inhibited reflex-evoked Isc responses $(n=4)$. This indicates that endogenous nucleotide release contributes to the stroking response. b Concentration-response curves for nucleotides in the presence of $1 \mu \mathrm{M} \mathrm{CPT}(n=4-23)$, an $\mathrm{A}_{1}$ receptor antagonist used to

provides a physiological brake to suppress reflex-evoked $\mathrm{Cl}^{-}$secretion elicited by stroking the mucosa by acting at $\mathrm{A}_{1}$ receptors located on EC cells [17, 18] and in the ENS [29]. Adenosine acts at $A_{1}$ receptors to suppress both the PG and 5-HT sensory limbs of mucosal secretory reflexes [29]. Our understanding of the role of $\mathrm{A}_{1}$ receptors in the modulation of mucosal reflexes is restricted to the guinea pig colon; however, it is likely this effect will occur in other regions, given that the $A_{1}$ receptor provides inhibition of synaptic transmission in myenteric and submucous neurons, and in other regions including stomach antrum, jejunum, and ileum $[8,20,22]$.

\section{Distribution of adenosine, $\mathrm{P} 2 \mathrm{X}$, and $\mathrm{P} 2 \mathrm{Y}$ receptors and gene products in ENS}

Immunohistochemical, gene chip microarray, quantitative reverse transcriptase polymerase chain reaction (RT-PCR), or in situ hybridization data have identified various purinergic receptors in the gut of various species. These

block eADO effects. The rank order of potencies of nucleotide agonists for stimulation of Isc was 2MeSADP $=2 \mathrm{MeSATP}>$ UTP $=$ UDP that indicates a $\mathrm{P} 2 \mathrm{Y}_{1} \mathrm{R}$ interaction. c The selective $\mathrm{P} 2 \mathrm{Y}_{1} \mathrm{R}$ antagonist MRS2179 suppresses $\sim 50 \%$ of the stroking response. d The Isc response to the $\mathrm{P} 2 \mathrm{Y}_{1} \mathrm{R}$ agonist $2 \mathrm{MeSADP}$ was nearly abolished by the $\mathrm{P} 2 \mathrm{Y}_{1} \mathrm{R}$ antagonist MRS2179 $(10 \mu \mathrm{M}, n=4, p<0.05)$. All experiments were done in the presence of $1 \mu \mathrm{M}$ CPT to eliminate inhibitory influence of $\mathrm{A}_{1}$ receptor activation by endogenous adenosine $\left(n>/ 4,{ }^{*} p<0.05\right)$ (Modified from [27] by permission)

include $\mathrm{A}_{1}, \mathrm{~A}_{2 \mathrm{a}}, \mathrm{A}_{2 \mathrm{~b}}, \mathrm{~A}_{3}, \mathrm{P} 2 \mathrm{X}_{2}, \mathrm{P} 2 \mathrm{X}_{3}, \mathrm{P} 2 \mathrm{X}_{5}, \mathrm{P} 2 \mathrm{X}_{7}, \mathrm{P} 2 \mathrm{Y}_{2}$, $\mathrm{P}_{2} \mathrm{Y}_{4}, \mathrm{P}_{2} \mathrm{Y}_{6}, \mathrm{P} 2 \mathrm{Y}_{12}$, and $\mathrm{P} 2 \mathrm{Y}_{14}$ receptors in the ENS of guinea pig, mouse, rat, or human intestine $[14,17-19,25$, 27, 29, 49, 93, 94, 108, 109, 117-119].

Differential gene and receptor expression of adenosine $A_{1}, A_{2 a}, A_{2 b}$, and $A_{3}$ receptors in the human enteric nervous system

Adenosine $A_{1}, A_{2 a}, A_{2 b}$, and $A_{3}$ receptor gene products were differentially expressed in neural and non-neural layers of the human jejunum, ileum, cecum, and colon as well as T-84, HT-29, T98G, and BON/EC cells or in PGP 9.5-ir enteric neurons [19]. Table 1 summarizes adenosine receptor mRNA expression levels in the different layers and cells using RT-PCR. With the exception of the $\mathrm{A}_{1}$ receptor, mRNA transcripts for $\mathrm{A}_{2 \mathrm{~b}}, \mathrm{~A}_{2 \mathrm{a}}$, and $\mathrm{A}_{3}$ receptors are expressed throughout the GI tract in epithelial cells, mucosa, and submucosa suggesting a significant role in secretomotor behavior of the human gut. 

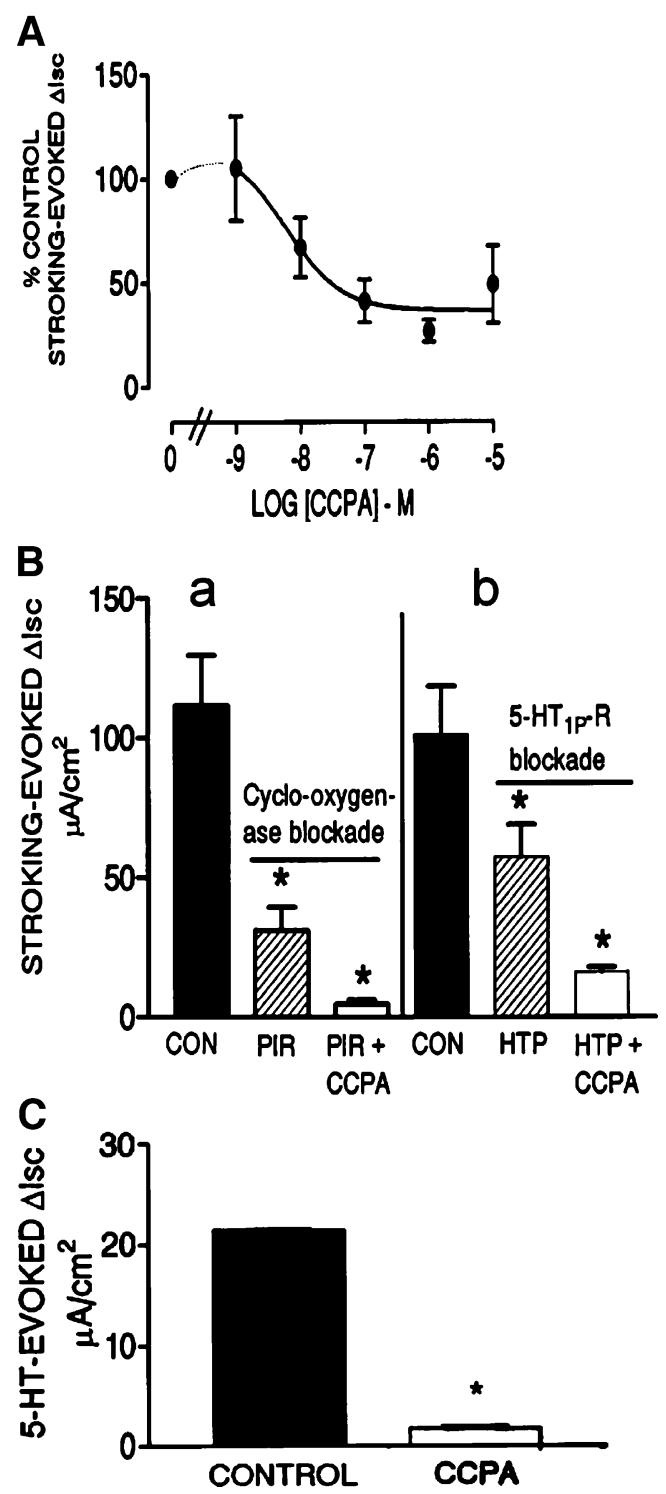

Fig. 8 Effect of CCPA on stroking-evoked change in Isc. A Concentration-response curve $\left(\mathrm{EC}_{50}=6 \mathrm{nM}, n=3-6\right)$. B Effect of CCPA $(0.1 \mu \mathrm{M})$ on 5-HT- and PG- mediated limb of reflex pathway. $a$ Presence of 5-HT limb after blockade of prostaglandin synthesis with $10 \mu \mathrm{M}$ piroxicam (PIR) $(n=5) . b$ Presence of PG limb after blockade of 5-HT limb with 1-10 $\mu \mathrm{M} \mathrm{N}$-acetyl-5-hydroxytryptophyl-5-hydroxytryptophan amide (HTP) ( $n=6$ or 7$)$. Con control, $p<0.05$ from control and PIR or HTP. C Effect of CCPA $(0.1 \mu \mathrm{M})$ on change in Isc evoked by a mucosal pulse of 5 -HT $(1 \mu \mathrm{M})(n=3) ; p<0.05$ (Modified from [29] by permission)

Cellular localization of adenosine receptor immunoreactivity is summarized in Table 2 . Adenosine $\mathrm{A}_{3}$ immunoreactivity is also expressed in a majority of substance $\mathrm{P}$ $(\sim 60 \%)$ and $<10 \%$ of VIP submucous neurons. In contrast to $\mathrm{A}_{3} \mathrm{R}$ receptors, $\mathrm{A}_{2 \mathrm{~b}}$ immunoreactivity is prominent in $50 \%$ of VIP neurons and not expressed in SP neurons in jejunum, but is expressed mainly in non-VIP neurons in colonic submucous neurons. Therefore, $\mathrm{A}_{2 \mathrm{~b}}$ receptors and $\mathrm{A}_{3}$ receptors may serve different roles in secretomotor function in the two regions by acting at putative secretomotor or sensory neurons, respectively.

$\mathrm{A}_{2 \mathrm{a}}$ immunoreactivity is found in a subset of VIP neurons. Varicose fibers in submucous ganglia label for $\mathrm{A}_{2 \mathrm{a}}$ or $\mathrm{A}_{2 \mathrm{~b}}$ immunoreactivity. $\mathrm{A}_{2 \mathrm{a}}$ and $\mathrm{A}_{2 \mathrm{~b}}$ immunoreactivity is prominent in submucous neurons, but only expressed in a minority of myenteric neurons. Immunoreactivities for $A_{2 a}$ and $\mathrm{A}_{2 \mathrm{~b}}$ receptors are colocalized in submucous neurons of the jejunum and colon (and jejunal myenteric neurons) as well as in epithelial cells of the jejunum (only region studied). $A_{2 b}$ immunoreactivity was also intensely expressed in s-100 positive glia in both nerve plexuses.

$\mathrm{A}_{1}$ immunoreactivity is abundantly expressed in submucous neurons of the colon, but was undetectable in submucous neurons of the jejunum. This is consistent with functional studies on synaptic $\mathrm{Ca}^{2+}$ responses in submucous neurons illustrating a lack of effect of $\mathrm{A}_{1}$ receptor antagonists

Table 1 RT-PCR to detect human adenosine receptor mRNA in human intestine

\begin{tabular}{|c|c|c|c|c|}
\hline & $\mathrm{A}_{1}$ & $\mathrm{~A}_{2 \mathrm{a}}$ & $\mathrm{A}_{2 \mathrm{~b}}$ & $\mathrm{~A}_{3}$ \\
\hline \multicolumn{5}{|l|}{ Jejunum } \\
\hline Whole thickness & $-(-)$ & $-(+)$ ? & ++ & ++ \\
\hline Mucosa/submucosa & $-(-)$ & ++ & ++ & + \\
\hline Mucosa & $-(-)$ & + & ++ & + \\
\hline Mucosa & $-(+) ?$ & ++ & ++ & ++ \\
\hline Submucous plexus & $-(+)$ & $-(+)$ & + & + \\
\hline Longitudinal/circular & $+(++)$ & ++ & ++ & + \\
\hline \multicolumn{5}{|l|}{ Ileum } \\
\hline Whole thickness & $+(+)$ & ++ & + & + \\
\hline Mucosa/submucosa & ND & ND & ND & ND \\
\hline Mucosa & $-(+)$ & ++ & + & + \\
\hline Submucous plexus & ND & ND & ND & ND \\
\hline \multicolumn{5}{|l|}{ Cecum } \\
\hline Whole thickness & $-(-)$ & + & ++ & + \\
\hline Mucosa/submucosa & $-(+)$ & ++ & + & + \\
\hline Mucosa & $-(-)$ & + & ++ & + \\
\hline Submucous plexus & $-(+)$ & $-(-)$ & + & $-(+)$ \\
\hline \multicolumn{5}{|l|}{ Colon } \\
\hline Whole thickness & $-(-)$ & $-(-)$ & + & $-(+)$ ? \\
\hline Mucosa/submucosa & $-(-)$ & $-(-)$ & ++ & + \\
\hline Mucosa & ND & ND & ND & ND \\
\hline Submucous plexus & $-(+)$ & $-(+)$ ? & ++ & + \\
\hline \multicolumn{5}{|l|}{ Human cell lines } \\
\hline HT-29 (colonic epithelium) & $+(+)$ & +++ & +++ & $-(-) ?$ \\
\hline T-84 (colonic epithelium) & $-(+)$ & + & +++ & $-(-) ?$ \\
\hline T98G (glioblastoma) & ++ & +++ & +++ & $-(+)$ \\
\hline
\end{tabular}

$N D$ not done, + or - indicate receptor mRNA detected or not detected, respectively. Failure to detect adenosine receptor mRNA after the first round of PCR reflects either absence or low expression. If the results of RT-PCR were negative, an aliquot of the first PCR reaction was amplified a second time, and the result is indicated in parentheses. Failure to detect adenosine receptor mRNA after the second round of PCR is likely to be due to its absence. A question mark indicates a possible faint expression of receptor mRNA. (Modified from [19] by permission) 
Table 2 Cellular localization of adenosine $A_{1}, A_{2 a}, A_{2 b}$, and $A_{3}$ receptor immunoreactivities in human small and large intestine

\begin{tabular}{lllll}
\hline Human intestinal region/cell type & $\mathrm{A}_{1}$ & $\mathrm{~A}_{2 \mathrm{a}}$ & $\mathrm{A}_{2 \mathrm{~b}}$ & $\mathrm{~A}_{3}$ \\
\hline Jejunum & & & & + \\
Longitudinal muscle & \pm & \pm & - & \\
Myenteric plexus neurons & + & + & + & \\
Glia & - & - & ++ & \\
Circular muscle & + & - & - & \\
Submucous plexus neurons & - & +++ & ++ & \\
Nerve fibers/neurites & - & + & + & + \\
Epithelia & - & + & + & + \\
Colon & & & & + \\
Longitudinal muscle & \pm & - & - & \\
Myenteric plexus neurons & - & + & + & \\
Glia & - & - & + & \\
Circular muscle & + & + & + & \\
Submucous plexus neurons & +++ & + & + & \\
Epithelia & + & & & \\
T98G & & & & + \\
U373 & & & & + \\
BON cells & & & & + \\
\hline
\end{tabular}

- absent, + present (or present $\leq 2$ neurons), \pm marginally detectable, ++ 3-6 neurons, $+++>6$ neurons. (Modified from [19] by permission)

expected to block ongoing inhibitory effects of endogenous adenosine at neural receptors and enhance synaptic transmission, as revealed in other tissues with functional $A_{1}$ receptors (see later discussion; [9, 21]). In addition, strong $\mathrm{A}_{1}$ immunoreactivity is found in epithelial cells of the human colonic mucosal glands, and mRNA and proteins expressed in two human epithelial cell lines. Therefore, $\mathrm{A}_{1}$ receptors could potentially play a role in submucosal neural reflexes, leading to suppression of intestinal secretion in the human gut as reported for the guinea pig colon [29]. The diverse but receptor-specific localization and expression of the four adenosine receptors in submucous neurons, glial cells, or epithelial cells, and the colocalization of $\mathrm{A}_{2 \mathrm{a}}$ and $\mathrm{A}_{2 \mathrm{~b}}$ receptors in submucous neurons or glandular epithelia, suggests a prominent and complex role for adenosine in the modulation of enteric neural reflexes that control secretomotor functions in the human digestive tract. Functional studies on adenosine receptors in human gut would be of physiological and clinical importance.

\section{Distribution of $\mathrm{P} 2 \mathrm{X}$ and $\mathrm{P} 2 \mathrm{Y}$ receptors in the enteric nervous system}

$\mathrm{P} 2 \mathrm{X}_{2}$ immunoreactivity has been identified in guinea pig ENS $[14,50,111]$. In submucous ganglia of the guinea pig ileum, $\mathrm{P} 2 \mathrm{X}_{2}$ immunoreactivity occurred in all VIP-positive neurons and calbindin-positive neurons making up about $50 \%$ of the neurons. In contrast, there was not any $\mathrm{P} 2 \mathrm{X}_{2}$ immunoreactivity in NPY or calretinin-positive neurons. Overall, $\mathrm{P} 2 \mathrm{X}_{2} \mathrm{R}$ are expressed in both nerve plexuses, in inhibitory motor neurons, IPANs of the myenteric plexus in stomach and intestine, on gastric endings of vagal afferent fibers, VIP noncholinergic secretomotor neurons, and IPANs of the submucous plexus [14]. In contrast to $\mathrm{P} 2 \mathrm{X}_{2}$, $\mathrm{P} 2 \mathrm{X}_{3}$ immunoreactivity in the submucous plexus occurs in most calretinin neurons that represent cholinergic neurons projecting to mucosa or arterioles, and make up $\sim 12 \%$ of the population [10]; therefore, the activity of some secretomotor neurons is likely to be modulated by $\mathrm{P} 2 \mathrm{X}_{3}$ receptors in guinea pig.

$\mathrm{P} 2 \mathrm{X}_{2}$ and $\mathrm{P} 2 \mathrm{X}_{3}$ immunoreactivity was also identified in nerve fibers in enteric ganglia, interganglionic fiber tracts, in the muscularis as well as in the perivascular plexus of the guinea pig gallbladder. $\mathrm{P} 2 \mathrm{X}_{2}$ or $\mathrm{P}_{2} \mathrm{X}_{3}$ neurons displayed immunoreactivity for VIP $(>90 \%)$ and NOS $(\sim 50-60 \%)$ [93]. The function of these receptors remains unknown.

$\mathrm{P} 2 \mathrm{X}_{2}$ and $\mathrm{P} 2 \mathrm{X}_{3}$ immunoreactivity was also localized in rat ENS, by in situ hybridization or mRNA levels [119]. Receptors were identified throughout the GI tract in both myenteric and submucous neurons. $\mathrm{P} 2 \mathrm{X}_{2}$ immunoreactivity (56\% ileum, 45\% distal colon) and $\mathrm{P} 2 \mathrm{X}_{3}$ immunoreactivity $(62 \%, 40 \%)$ was abundant in submucous neurons. $\mathrm{P} 2 \mathrm{X}_{2}$ immunoreactivity in submucous plexus colabeled for calbindin or calretinin in $30-50 \%$ of neurons. $\mathrm{P}_{2} \mathrm{X}_{3}$ immunoreactivity neurons expressed calretinin $(40 \%)$ and calbindin (30-75\%). Coexpression of $\mathrm{P}_{2} \mathrm{X}_{3}$ immunoreactivity in calbindin neurons also occurred in colorectum [116] but not in those in rat ileum $[85,108]$. At least in the mouse, $\mathrm{AH}$ sensory (not S/type 1) neurons did express $\mathrm{P}_{2} \mathrm{X}_{3}$ immunoreactivity [7]. Species and region differences may exist in distribution of the $\mathrm{P} 2 \mathrm{X}_{2}$ and $\mathrm{P} 2 \mathrm{X}_{3}$ receptors in submucous neurons (see $[7,14,49,93,111,118]$ ). The $\mathrm{P} 2 \mathrm{X}_{1}, \mathrm{P} 2 \mathrm{X}_{4}$, or $\mathrm{P} 2 \mathrm{X}_{6}$ receptor was undetectable in mouse ENS. The $\mathrm{P} 2 \mathrm{X}_{5}$ receptor is widely distributed in mouse GI tract in enteric ganglia in both nerve plexuses. In the submucous plexus, P2 $\mathrm{X}_{5}$ immunoreactivity discretely colocalize with $22 \%$ of calretinin, $9 \%$ of calbindin, $6 \%$ of nitric oxide synthase, and $68 \%$ of VIP-positive neurons. Therefore, the $\mathrm{P} \mathrm{X}_{5}$ receptor may be distributed in secretomotor and intrinsic sensory neurons. The mouse $\mathrm{P} 2 \mathrm{X}_{5}$ receptor could form heteromultimers with a unique pharmacology [94].

$\mathrm{P} 2 \mathrm{X}_{3}$ immunoreactivity has also been identified in submucous (and myenteric) neurons as well as in some axons/dendrites of the human colon [36, 122], but the identity of the subtypes of human neurons expressing $\mathrm{P} 2 \mathrm{X}_{3}$ immunoreactivity remains unclear. Future studies should include detailed analysis of the distribution of purinergic receptors in the human ENS.

$\mathrm{P}_{2} \mathrm{Y}_{2}$ immunoreactivity occurs in neurons and fibers in both myenteric and submucous plexuses in the corpus of 
the stomach, jejunum, ileum, and colon of the guinea pig [118]. $\mathrm{P}_{2} \mathrm{Y}_{2}$ immunoreactivity is prominent in neurons with Dogiel type I morphology. All P2X $\mathrm{X}_{3}$ neurons and none of the $\mathrm{P} 2 \mathrm{X}_{2}$ neurons in the submucous plexus (or $\sim 50 \%$ in myenteric neurons) coexpressed $\mathrm{P}_{2} \mathrm{Y}_{2}$ immunoreactivity throughout the GI tract. A majority of calretinin and NPY submucous neurons also expressed $\mathrm{P}_{2} \mathrm{Y}_{2}$ immunoreactivity. Submucosal neurons with $\mathrm{P} 2 \mathrm{X}_{3}$ and $\mathrm{P} 2 \mathrm{Y}_{2}$ receptor immunoreactivity with Dogiel type I morphology may represent a subset of S/type 1 neurons with Dogiel type I morphology that display both a fast P2X and slow P2Y membrane depolarization [3]. It has been suggested that a $\mathrm{P} 2 \mathrm{X}_{2}$ or $\mathrm{P}_{2} \mathrm{X}_{7}$ receptors may mediate the fast $\mathrm{P} 2 \mathrm{X}$ response in neurons that only display a fast response [3, 14, 49, 119]. Lack of $\mathrm{P}_{2} \mathrm{Y}_{2}$ immunoreactivity in calbindin submucosal neurons of the guinea pig gut argues against their expression on IPANs [39]. Regional differences occur in the colocalization of $\mathrm{P} 2 \mathrm{Y}_{2}$ immunoreactivity with $\mathrm{P} 2 \mathrm{X}_{3}$ immunoreactivity or in other types of neuronal markers. These receptors may play a role in regulation of mucosal secretory glands and the local vasculature.

The $\mathrm{P} 2 \mathrm{Y}_{6}$ receptor is widely distributed in myenteric but not submucous ganglia of the stomach, jejunum, ileum, and colon (in guinea pig), whereas the $\mathrm{P}_{2} \mathrm{Y}_{12}$ receptor is also widely distributed in submucous ganglia. $\mathrm{P}_{2} \mathrm{Y}_{12}$ and $\mathrm{P}_{2} \mathrm{Y}_{6}$ receptors and neurons likely play different roles in the gut. A distinction between their localization is that $\mathrm{P}_{2} \mathrm{Y}_{12}$ immunoreactivity (not $\mathrm{P}_{2} \mathrm{Y}_{6}$ ) is also expressed in calbindin intrinsic sensory neurons and not calretinin or NOS (in both plexuses). $\mathrm{P}_{2} \mathrm{Y}_{6}$ immunoreactivity is instead found in NOS and calretinin-positive neurons. Therefore, the $\mathrm{P}_{2} \mathrm{Y}_{12}$ receptor may play a role in sensory signaling in mucosal secretomotor reflexes.

\section{Mucosal epithelial cell lines and ion transport}

In human epithelial carcinoma cell lines (HCT8 and Caco-2), cells express mRNA for $\mathrm{P}_{2} \mathrm{X}_{1}, \mathrm{P}_{2} \mathrm{X}_{3}, \mathrm{P}_{2} \mathrm{X}_{4}, \mathrm{P}_{2} \mathrm{X}_{5}, \mathrm{P} 2 \mathrm{X}_{6}$, and $\mathrm{P}_{2} \mathrm{X}_{7}$ and $\mathrm{P} 2 \mathrm{Y}_{1}, \mathrm{P}_{2} \mathrm{Y}_{2}, \mathrm{P}_{2} \mathrm{Y}_{4}, \mathrm{P} 2 \mathrm{Y}_{6}, \mathrm{P}_{2} \mathrm{Y}_{11}$, and $\mathrm{P} 2 \mathrm{Y}_{12}$ receptors. In addition, $\mathrm{P} 2 \mathrm{Y}_{1}, \mathrm{P}_{2} \mathrm{Y}_{2}$, and $\mathrm{P} 2 \mathrm{X}_{1-7}$ receptor proteins are expressed in these cells. Functional studies on cell proliferation and apoptosis using selective agonists and antagonists suggested involvement of $\mathrm{P} 2 \mathrm{X}_{7}, \mathrm{P} 2 \mathrm{Y}_{1}, \mathrm{P} 2 \mathrm{Y}_{2}$, and $\mathrm{P} 2 \mathrm{Y}_{4}$ receptors but their role in secretion awaits further study [31].

\section{ENaC and CFTR channels}

$\mathrm{ENaC}$ mediate electrogenic absorption of $\mathrm{Na}^{+}$in intestine (and other epithelial tissues). $\mathrm{ENaC}$ in colonic epithelia is expressed together with the CFTR $\mathrm{Cl}^{-}$channels. Stimula- tion of purinergic receptors by ATP or activation of CFTR stimulate chloride secretion and inhibit amiloride-sensitive $\mathrm{Na}^{+}$transport $(\mathrm{ENaC})$. Inhibition of $\mathrm{ENaC}$ by nucleotides is not via CFTR-mediated ATP release [62]. ATP or UTP acting at P2YRs also activate $\mathrm{Ca}^{2+}$-dependent $\mathrm{Cl}^{-}$channels. $\mathrm{Na}^{+}$absorption in mouse colon (and airway epithelia) is inhibited by cell shrinkage (change in volume) by a mechanism that does not interfere with purinergic (or CFTR) mediated inhibition of $\mathrm{ENaC}$ [101]. A recent study in $\mathrm{P}_{2} \mathrm{Y}_{2}$ and $\mathrm{P}_{2} \mathrm{Y}_{4}$ knockout mice suggests that only the stimulation of the luminal $\mathrm{P}_{2} \mathrm{Y}_{2}$ receptor mediates inhibition of electrogenic $\mathrm{Na}^{+}$absorption via epithelial $\mathrm{Na}^{+}$ channels $(\mathrm{ENaC})$ in mouse colon. In contrast, luminal $\mathrm{P}_{2} \mathrm{Y}_{2}$ and $\mathrm{P}_{2} \mathrm{Y}_{4}$ receptors stimulate $\mathrm{K}^{+}$secretion [74].

\section{Luminal P2 and ion transport}

P2 receptors are found in both the basolateral and luminal membranes. A recent review by Leipziger (2003) summarizes the different $\mathrm{P} 2 \mathrm{X}$ and $\mathrm{P} 2 \mathrm{Y}$ receptors, their functions, and intracellular signaling pathways in all epithelial tissues.

Relevant information on gut luminal P2 receptors is summarized in Table 3. Several generalizations can be made from Table 3. Epithelial cells respond well to ATP and UTP. $\mathrm{P}_{2} \mathrm{Y}_{2}$ and $\mathrm{P}_{2} \mathrm{Y}_{4}$ receptors are very prevalent luminal receptors involved in $\mathrm{Cl}^{-}, \mathrm{HCO}_{3}^{-}, \mathrm{K}^{+}$secretion, or mucin secretion. Nucleotide stimulation of $\mathrm{K}^{+}$secretion occurs in the distal colon, $\mathrm{K}^{+}$secretion and $\mathrm{HCO}_{3}{ }^{-}$secretion in the gallbladder (Table 3; $[17,18,75,90]) ; \mathrm{HCO}_{3}{ }^{-}$secretion also occurs in ducts and is involved in the formation of pancreatic juice. Stimulation of $\mathrm{Cl}^{-}$secretion occurs in the gallbladder, small intestine, and duct cells. $\mathrm{Ca}^{2+}$ is the main second messenger coupled to $\mathrm{P} 2 \mathrm{Y}$ receptors, although cAMP can be involved as well. Region and species differences occur especially in $\mathrm{P}_{2} \mathrm{X}_{7}$ and $\mathrm{P}_{2} \mathrm{Y}_{6}$ receptors. Functional discrimination between $\mathrm{P}_{2} \mathrm{Y}_{2}$ and $\mathrm{P}_{2} \mathrm{Y}_{4}$ receptors is difficult because of the similar agonist potency profiles [102]. The persistence of a $\mathrm{Cl}^{-}$secretory response to UTP or ATP in $\mathrm{P}_{2} \mathrm{Y}_{2}^{-/-}$mice suggested that the response in mice could be mediated by $\mathrm{P}_{2} \mathrm{Y}_{4}$ receptors [32]. Indeed, loss of nucleotide regulation of epithelial chloride transport occurs in the jejunum of $\mathrm{P}_{2} \mathrm{Y}_{4}$-null mice [90]. $\mathrm{P}_{2} \mathrm{Y}_{4}$ mRNA are expressed in rat and guinea pig submucosa [17, 18, 27], murine colonic crypts [75], stomach and intestine [90, 105], and more recently in enteric glial cells [108, 109]. In the guinea pig small intestine, $\mathrm{P}_{2} \mathrm{Y}_{4}$ immunoreactivity is expressed in enteric glial cells (EGCs) in various regions of the GI tract except esophagus. EGCs are important regulators of barrier function, mucosal permeability, neuronal activity, and epithelial cell growth and are active participants in intestinal inflammation [13, 95]. Some discrepancy exists between studies on whether $\mathrm{P}_{2} \mathrm{Y}_{4}$ 
Table 3 Functional distribution of luminal P2 receptors in GI epithelial cells

\begin{tabular}{|c|c|c|c|c|c|c|}
\hline Tissue & Species & $\mathrm{P} 2$ receptor & Endog. agonist & Function & Signaling & Reference \\
\hline Jejunum & Mouse & $\mathrm{P}_{2} \mathrm{Y}_{4}$ & $\mathrm{ATP}=\mathrm{UTP}$ & $\mathrm{Cl}^{-}$secretion $\uparrow$ & & 32 \\
\hline Duod. villus & Rat & $\mathrm{P} 2 \mathrm{X}_{7}$ & & Apoptosis ?? & & 43 \\
\hline \multirow[t]{4}{*}{ Pancr. duct } & Guinea pig & $\mathrm{P} 2 \mathrm{Y}_{2}$ & $\mathrm{ATP}=\mathrm{UTP}$ & $\mathrm{HCO}_{3}^{-}$secretion $\uparrow$ & $\mathrm{Ca}^{2+} \uparrow$ & 52 \\
\hline & Rat & $\mathrm{P} 2 \mathrm{X}_{7}$ & Bz-ATP & & $\mathrm{Ca}^{2+} \uparrow$ & 47 \\
\hline & Rat & \multirow[t]{2}{*}{$\mathrm{P} 2 \mathrm{Y}_{2}, \mathrm{P}_{2} \mathrm{Y}_{4}, \mathrm{P} 2 \mathrm{X}_{7}$} & UTP/ATP & $\mathrm{Cl}^{-}$secretion $\uparrow$ & $\mathrm{Ca}^{2+} \uparrow$ & 72 \\
\hline & Dog & & ATP & Mucin secret. $\uparrow$ & $\mathrm{Ca}^{2+} \uparrow$ & 81 \\
\hline PDEC & Human & $\mathrm{P} 2 \mathrm{Y}_{2} / \mathrm{P} 2 \mathrm{Y}_{4}$ & UTP/ATP & $\mathrm{Cl}^{-}$secretion $\uparrow$ & $\mathrm{Ca}^{2+} \uparrow$ & 16 \\
\hline CFPAC-1 & Mouse & $\mathrm{P} 2 \mathrm{Y}_{2} / \mathrm{P} \mathrm{Y}_{6}$ & $\mathrm{ATP}=\mathrm{UTP} / \mathrm{UDP}$ & $\mathrm{Cl}^{-}$secretion $\uparrow$ & & 32 \\
\hline \multirow[t]{2}{*}{ Gallbladder } & Mouse & $\mathrm{P} 2 \mathrm{Y}_{2}$ & ATP/UTP & $\mathrm{HCO}_{3}{ }^{-}$secret. $\uparrow$ & $\mathrm{Ca}^{2+} \uparrow$ & 23 \\
\hline & Necturus & $\mathrm{P} 2$ & АTP & $\mathrm{Cl}^{-}$secretion $\uparrow$ & $\mathrm{cAMP} \uparrow$ & 107 \\
\hline \multirow[t]{4}{*}{ Bile duct } & \multirow[t]{3}{*}{ Rat } & $\mathrm{P} 2 \mathrm{Y}_{1}, \mathrm{P} 2 \mathrm{Y}_{2}$ & ATP, UTP & \multirow[t]{3}{*}{$\mathrm{HCO}_{3}{ }^{-}$secret. $\uparrow$} & & \\
\hline & & $\mathrm{P} 2 \mathrm{Y}_{4}, \mathrm{P}_{2} \mathrm{Y}_{6}$ & ADP, UDP & & & \\
\hline & & & 2MeSATP & & & \\
\hline & Rat & $\mathrm{P} 2 \mathrm{Y}_{2} / \mathrm{P} 2 \mathrm{Y}_{4}$ & UTP/ATP & $\mathrm{Cl}^{-}$secretion $\uparrow$ & & 96,100 \\
\hline \multirow[t]{2}{*}{ Colon } & \multirow[t]{2}{*}{ Rat, mouse } & \multirow{2}{*}{$\mathrm{P} 2 \mathrm{Y}_{2} / \mathrm{P} 2 \mathrm{Y}_{4}$} & \multirow[t]{2}{*}{ UTP/ATP } & $\mathrm{K}^{+}$secretion $\uparrow$ & $\mathrm{Ca}^{2+} \uparrow$ & \multirow[t]{2}{*}{56} \\
\hline & & & & $\mathrm{Na}^{+}$absorption $\downarrow$ & $?$ & \\
\hline Caco-2 & Human & $\mathrm{P} 2 \mathrm{Y}_{2}, \mathrm{P} 2 \mathrm{Y}_{4}, \mathrm{P} 2 \mathrm{Y}_{6}$ & UTP/ATP & $\mathrm{Cl}^{-}$secretion $\uparrow$ & $\mathrm{Ca}^{2+} \uparrow$ & 76 \\
\hline
\end{tabular}

immunoreactivity occurs in epithelial cells, but EGCs may play a role in the modulation of ion transport in gut epithelial cells (for review see [95]).

Little evidence exists that luminal $\mathrm{P} 2$ receptors activate absorption, other than the preposition that a $\mathrm{P} 2 \mathrm{X}_{7}$ receptor is involved in stimulation of $\mathrm{Na}^{+} / \mathrm{H}^{+}$exchanger type 3mediated $\mathrm{Na}^{+}$absorption in rat submandibular gland ducts [66]. In contrast, data suggest that luminal fluid secretion and a diarrhea response would occur with activation of luminal $\mathrm{P} 2 \mathrm{Y}$ receptors in small intestine $\left(\mathrm{Cl}^{-}\right.$secretion) or colon (inhibition of $\mathrm{Na}^{+}$absorption via $\mathrm{ENaCs}$ and $\mathrm{K}^{+}$secretion); a diarrhea response may play a role in host defense reactions against potential pathogenic invading organisms. Another possibility is that the $\mathrm{P} 2 \mathrm{X}_{7}$ receptor in villus tip cells that undergo programmed cell death and exfoliation may act as a "death signal" to insure villus cell regeneration [43]. The $\mathrm{P}_{2} \mathrm{Y}_{6}$ receptor is a potential therapeutic target in the treatment of cystic fibrosis gallbladder disease because UDP retained its ability to promote/stimulate Isc/ion transport changes in cystic fibrosis gallbladder epithelial cells from CFTR-deficient mice [65].

\section{Basolateral $\mathrm{P}^{2} \mathrm{Y}_{6}$ stimulates $\mathrm{NaCl}$ secretion}

Recent evidence suggests that basolateral $\mathrm{P} 2 \mathrm{Y}_{6}$ receptors that are sensitive to UDP in colonic epithelia cells stimulate sustained $\mathrm{NaCl}$ secretion by evoking a synergistic increase in intracellular free $\mathrm{Ca}^{2+}$ and cAMP. In Xenopus oocytes coexpressing $\mathrm{P}_{2} \mathrm{Y}_{6}$ with the cystic fibrosis transmembrane conductance regulator (CFTR), UDP transiently activated the $\mathrm{Ca}^{2+}$-activated $\mathrm{Cl}^{-}$current and subsequently CFTR.

\section{$A_{2 b}$ receptors in apical secretion}

Adenosine is generated at sites of tissue injury or stress including ischemia, inflammation, and tissue remodeling by ATP catabolism. Adenosine at inflammatory sites can have either proinflammatory or anti-inflammatory effects depending on the receptor or tissue. In crypt abscesses during periods of active inflammation, ectonucleotidases convert ATP derived from neutrophils to adenosine. Adenosine causes vectorial chloride and interleukin-6 secretion [33, 73, 103]. In human jejunum, an $\mathrm{A}_{2}$ receptor agonist $5^{\prime}-N$-methylcarboxamidoadenosine stimulates chloride secretion. $\mathrm{A}_{2 \mathrm{~b}}$ immunoreactivity is prominent in human mucosa or epithelial cells of the cecum, colon, and jejunum (Christofi et al. 1999; [89, 104]).

At rest, in epithelial cells, the $\mathrm{A}_{2 b}$ receptor is intracellular and inactive, and agonist stimulation on the apical or basolateral side of human epithelial cells induces polarized trafficking and surface expression of the $\mathrm{A}_{2 \mathrm{~b}}$ receptor in intestinal epithelial cells [33]. $N$-ethylmaleimide attachment receptor (SNARE) proteins participate in recruitment of $A_{2 b}$ receptors that may be necessary for its signaling. The $\mathrm{A}_{2 b}$ receptor signals through the $\mathrm{cAMP} /$ protein kinase $\mathrm{A} / \mathrm{cAMP}$ response-element binding protein to cause apical chloride and interleukin-6 secretion. It has been suggested that interleukin-6 would promote neutrophil degranulation 
and enhance microbicidal activity of neutrophil trafficking to the intestinal mucosa [103].

\section{Purinergic regulation of secretion from neuroendocrine cells in gastric mucosa}

Al/gastrin release In the stomach, adenosine protects against stress-induced gastric ulcer formation by inhibiting gastric acid secretion by direct action on parietal cells in some species (guinea pigs and dogs, [42, 48]) but not others (rats, [86]). A recent study using selective $\mathrm{A}_{1}$ (N6cyclopentyladenosine), $A_{2 a}$ (CGS 2168), and $A_{3}$ (IBMECA) receptor agonists provided pharmacological proof that an $A_{1}$ receptor is negatively coupled to gastrin release in rat stomach. An $\mathrm{A}_{1}$ receptor selective antagonist 8cyclopentyl-1,3-dipropyl-xanthine abolished adenosine effects on gastrin release, and $A_{1}$ immunoreactivity was found on mucosal G cells (gastrin) and D cells (somatostatin), but not parietal cells $\left(\mathrm{H}^{+}\right.$ions, acid). Therefore, adenosine may suppress gastrin release by activating $\mathrm{A}_{1}$ receptors on $\mathrm{G}$ cells, leading to inhibition of gastric acid secretion $[123,125]$.

Omeprazole-induced achlorhydria suppresses gene expression of both $A_{1}$ and $A_{2 a}$ receptors in the antrum and corpus mucosa. In the vascularly perfused rat stomach, omeprazole also significantly attenuated the $\mathrm{A}_{2 \mathrm{a}}$ receptormediated stimulation of somatostatin release along with a corresponding decrease in $\mathrm{A}_{2 \mathrm{a}}$ receptor mRNA expression. This acid-dependent change in $\mathrm{A}_{2 \mathrm{a}}$ receptor expression is a regulatory feedback mechanism to control gastric acid secretion [124]. The $\mathrm{A}_{2 \mathrm{a}}$ receptor agonist ATL-146e could almost prevent aspirin-induced gastric mucosal lesions [83].

Clinical implications of adenosine deaminase (ADA) activity Clinical studies suggest that adenosine inhibits gastric acid secretion and may act as a gastroprotective agent. For instance, patients suffering from acid hypersecretion have higher ADA activity. There is a direct correlation between ADA activity and gastric acid output in fundic mucosa of patients with ulcer, gastritis, and achlorhydria [79]. In patients with gastric ulcers, corpus mucosa ADA activity is reduced after $\mathrm{H} 2$ blocker ranitidine treatment [80].

$A_{2 a}$ receptors and somatostatin release Adenosine administration to the isolated vascularly perfused rat stomach inhibits gastrin release and stimulates somatostatin release [64], a potent inhibitor of gastric acid secretion. Adenosine analogs augment somatostatin-like immunoreactivity release with a potency profile of CGS $21680=$ 5 - $N$-ethylcarboxamidoadenosine $>2$-chlroadenosine $>$
R-(-)-N6-(2-phenylisopropyl)adenosine >1-deoxy-1-[6[[3-iodophenyl)methyl]amino]-9H-purin-9-yl]- $N$-methyl$\beta$-D-ribofuranuronamide $>N 6$-cyclopentyladenosine $=$ N6-cyclohexyladenosine $>S$-(+)-N6-(2-phenylisopropyl) adenosine, suggesting an $\mathrm{A}_{2 \mathrm{a}}$ receptor involvement. The $\mathrm{A}_{2 \mathrm{a}}$ receptor antagonist ZM 241385 abolished the CGS 21680 or adenosine stimulation of somatostatin release. Immunochemical distribution of $\mathrm{A}_{2 \mathrm{a}}$ receptors suggests that adenosine can act on $\mathrm{D}$ cells or indirectly on myenteric neurons to stimulate somatostatin release and consequently suppress gastric acid secretion [125].

Gastric preconditioning induced by short ischemia (brief occlusion of celiac artery for $5 \mathrm{~min}$ ) protects against mucosal damage induced by severe ischemia/reperfusion or topical mucosal irritants in the stomach. Adenosine release among other mediators [63] contributes to protection. Adenosine pretreatment $(10 \mathrm{mg} / \mathrm{kg}$ i.g. $)$ reduced lesions and improved gastric blood flow similar to ischemic preconditioning. The adenosine receptor antagonist 8phenyltheophiline $(10 \mathrm{mg} / \mathrm{kg}$ i.g.) attenuated the gastroprotection due to preconditioning. Furthermore, the selective $\mathrm{A}_{2 \mathrm{a}}$ receptor agonist ATL-146e $(5 \mu \mathrm{g} / \mathrm{kg})$ attenuated stressinduced gastric lesions and damage and reduced production of proinflammatory cytokines [tumor necrosis factor (TNF)- $\alpha$, interleukin (IL)-1 $\beta$ ] and neutrophil infiltration, suggesting a protective effect via $\mathrm{A}_{2}$ receptors against ulcer formation [82].

\section{Reflex-driven intestinal diarrhea and clinical relevance of purines}

The therapeutic potential of purinergic receptors in intestinal secretomotor disorders remains to be established, but evidence is building in support of endogenous adenosine, $\mathrm{A}_{2 \mathrm{a}}$, and $\mathrm{A}_{3}$ receptors as therapeutic targets. Toxin A (TxA) release from Clostridium difficile (a gram-positive anaerobic bacillus) can contribute to antibiotic-induced diarrhea and pseudomembranous colitis; the latter condition is associated with significant mucosal secretion and inflammation. The neural circuit mechanism deduced from the available evidence is shown in Fig. 9. Briefly, activation of nuclear factor NF-KB initiates a cascade of events involving epithelial cells, macrophages, neutrophils, mast cells, extrinsic primary afferent neurons (EPANs), and the ENS including cholinergic secretomotor neurons. Eventual hyperexcitability of neural circuits leads to amplification of the secretory response and profuse secretion to flush out the pathogenic organism [25]. The selective $A_{2 a}$ receptor agonist ATL $313(0.5-5 \mathrm{nM})$ also reduced Clostridium difficile TxA-induced secretion and edema, prevented the mucosal damage and neutrophil infiltration, TxA-induced 


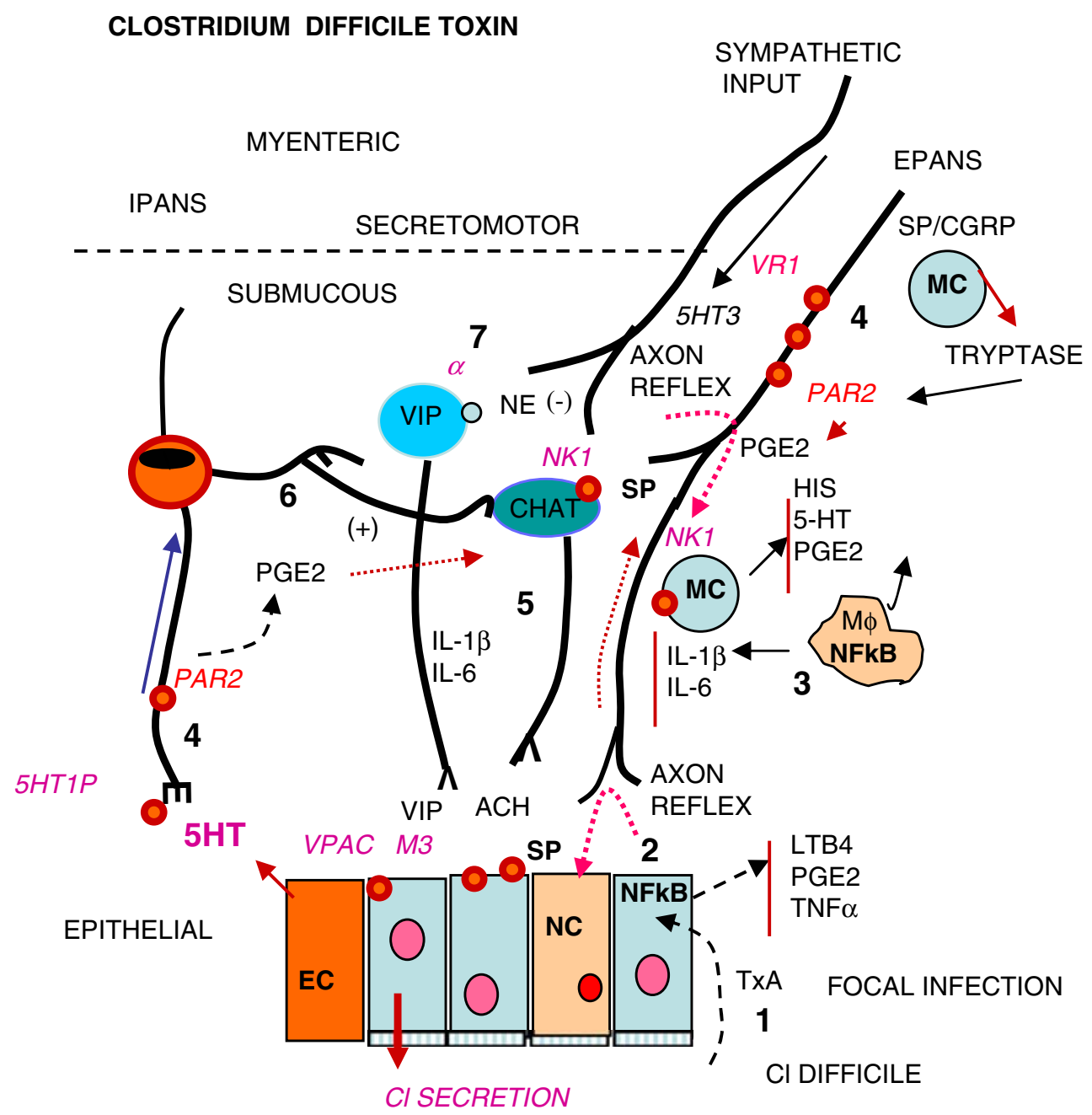

Fig. 91 Clostridium difficile toxin A $(T x A)$ stimulates reflex-evoked intestinal secretion and causes diarrhea. 2 After TxA is internalized in enterocytes, TxA activates NF-kB and releases LTB4, PGE2, TNF. 3 After NF-kB activation, the proinflammatory mediators interleukins $(I L)$ are released from monocytes/macrophages (MO). 4 Stimulation of processes of EPANS occurs, followed by release of substance P $(S P) /$ CGRP that degranulates mast cells $(M C)$ by activating NK1 receptors. 5 SP-containing EPANS release SP on cholinergic secretomotor neurons. The mediators released from mast cells include histamine, 5-HT, PGE2, and tryptase. 6 Tryptase acts on PAR2 receptors on

cell death, TNF- $\alpha$ production, as well as increased ileal ADA activity, in murine ileal loops exposed to TxA. Effects were reversed by the selective $\mathrm{A}_{2 \mathrm{a}}$ receptor antagonist ZM241385 (5 nM) [15].

Recent studies provided convincing evidence that activation of an $\mathrm{A}_{2 \mathrm{a}}$ receptor attenuates intestinal inflammation in animal models of IBD and may serve as a novel therapy for IBD $[15,77,82]$. In general, adenosine has diverse functions in the GI tract in the regulation of secretion, motility, innate mucosal immunity, is protective against experimental IBD, and is important in mediating inflammatory responses at sites of injury, and has anti-inflammatory effects in epithelial cells.
EPANS and on IPANS to stimulate further release of PGE2. 7 The sympathetic innervation with norepinephrine release and its binding to $\alpha 2$-adrenergic receptors normally reduces secretion via VIP secretomotor neurons. ILs suppress norepinephrine release. These cytokines act on sympathetics to lift the sympathetic brake exerted by norepinephrine. TxA-induced release of proinflammatory mediators degranulates mast cells that amplify neural and secretory responses in order to maximize secretion in defense of the host. Treatment with an $\mathrm{A}_{2 \mathrm{a}}$ receptor agonist attenuates the TxA-induced diarrhea presumably by acting in this reflex pathway. (Modified from [25] by permission)

Adenosine is also reported to be a conditionally essential nutrient for the gut and has been shown to be beneficial in alleviating severe diarrhea in children with cholera [20, 25, 98].

Recent findings indicate that lumenal adenosine or AMP can rapidly increase glucose transport by small intestine and increase systemic availability of 3-O-methyl glucose after an oral administration to mice. The putative $A_{2}$ receptor involved is linked to a signaling pathway involving cAMP production. Adenosine causes a rapid increase in carriermediated glucose uptake that is suggested to be of clinical relevance [60]. In contrast to other modulators, adenosine is a natural component of the diet, and this alone or as 
supplement in the diet may suggest potential applications in treatment of malabsorption in chronic intestinal inflammatory diseases. Daily intake of purines is $600-1,000 \mathrm{mg} / \mathrm{day}$ by adult individuals in the USA [99]. It has been estimated that diet and endogenous adenosine production can contribute 5-6 mM of adenosine in the lumen in individuals on a Western diet. A concentration of $1 \mathrm{mM}$ luminal adenosine caused a maximum effect on glucose uptake [60].

In human intestinal epithelial cells, adenosine affects immune function and exerts anti-inflammatory effects by acting as a negative regulator of $N F-\kappa B$ and MAPK signaling. Adenosine pretreatment in HT-29 cells caused a reduction in stimulated IL-8 expression and secretion [55].

\section{Neurogenic diarrhea}

The adenosine $\mathrm{A}_{3}$ receptor is one of the least understood receptors in secretomotor reflexes. The physiological relevance of $\mathrm{A}_{3}$ receptor is unclear, and current opinion is that it may function primarily in disease or abnormal states such as ischemia/reperfusion injury, tissue damage, gut inflammation, and extremes in motor activity of the gut when endogenous adenosine release is sufficiently high to activate the low affinity receptor [53]. It has been reported by Cooke et al. [30] that dimaprit- $\mathrm{H}_{2} \mathrm{R}$ activation of submucous neurons leads to a stereotypical cyclical pattern of secretion in coordination with motility that can last for several hours. The underlying electrophysiological correlate is cyclical depolarization and excitation of submucous neurons. This is a model of neurogenic diarrhea involving an immune-neural circuit. It proved useful in elucidating a functional role of $\mathrm{A}_{3}$ receptors in addition to $\mathrm{A}_{1}$ receptors in the secretomotor function and coordination of motility and secretion [8, 9]. Dimaprit was used to elicit a stereotypical cyclical increase in short-circuit current (Isc $=$ chloride secretion) in coordination with motility. Isc was recorded in guinea pig distal colon simultaneously with muscle length in the circular orientation by sonomicrometry. $\mathrm{A}_{1}$ receptorselective antagonists 8-cyclopentyltheophylline (CPT) or 1,3-dipropyl-8-(2-amino-4-chlorophenyl) xanthine (PACPX) or the irreversible antagonist FSCPX caused a concentrationdependent augmentation of coordinated responses; $100 \mathrm{nM}$ antagonist caused maximum blockade of $\mathrm{A}_{1}$ receptors and enhanced Isc $133 \%$ and ICD $64 \%$ with $\mathrm{ED}_{50}$ values in the nanomolar concentration range. Dimaprit responses were abolished by $10 \mathrm{nM} \mathrm{A}_{1}$ receptor agonist CCPA and reversed by $A_{1}$ receptor antagonists. After knockdown of $A_{1}$ receptors with FSCPX $(1 \mu \mathrm{M})$, the selective $\mathrm{A}_{3}$ receptor agonist IB-MECA could still abolish coordinated responses $\left(\mathrm{IC}_{50^{-}}\right.$ Isc $\left.=2.1 \mu \mathrm{M} ; \mathrm{IC}_{50}-\mathrm{ICD}=7.1 \mu \mathrm{M}\right)$ that could be reversed by the $A_{3}$ receptor antagonist $M R S 1191$. The $A_{3}$ receptor antagonist alone could also enhance Isc and coordinated muscle responses. The coordinated response to dimaprit is abolished by nerve blockade with TTX, and remaining myogenic activity was reduced by $\sim 50 \%$ by IB-MECA after $\mathrm{A}_{1}$ receptor knockdown with FSCPX. MRS1191 (1 $\left.\mu \mathrm{M}\right)$ could enhance TTX-sensitive distension-evoked Isc responses. $\mathrm{A}_{3}$ receptor immunoreactivity occurs in myenteric and submucous neurons of guinea pig, mouse, rat, and human colon (Christofi, unpublished observations). Availability of knockout models for adenosine receptor subtypes should provide unequivocal proof of function.

In summary, preliminary data suggest that in a model of neurogenic diarrhea endogenous adenosine release is sufficient to act at inhibitory $A_{1}$ and $A_{3}$ receptors to modulate the stereotype neural-motor behavior triggered by the mast cell mediator histamine. Adenosine $\mathrm{A}_{3}$ receptors may be targets for modulation of distension-evoked neurosecretory reflexes as well. The role of $\mathrm{A}_{3}$ receptors in bowel disorders associated with diarrhea or diarrhea predominant IBS warrants further investigation.

\section{Differential dysregulation of purinoceptors in GI disease states}

As already described, purinergic signaling regulates all important physiological functions of the GI tract including epithelial transport, 5-HT release from EC cells, mucosal reflexes, sensory signaling in the ENS, synaptic transmission, as well as coordination of motility and secretion. It is reasonable then to suggest that these abnormalities in purinergic receptors or signaling pathways would have a significant impact on the overall behavior of the gut, enteric reflexes, and secretomotor behavior of the gut in bowel diseases. Purinergic receptors in gastrointestinal inflammation were the subject of a recent review by Kolachala et al. [61]. A recent study by Guzman et al. [45] using high-density oligonucleotide microarray analysis and SYBR-Green RT-PCR validation provided direct proof for differential dysregulation (upregulation or downregulation depending on the purine gene) of $\mathrm{P} 2 \mathrm{X}_{1}, \mathrm{P} 2 \mathrm{X}_{2}, \mathrm{P} 2 \mathrm{X}_{4}, \mathrm{P} 2 \mathrm{X}_{7}$, $\mathrm{P}_{2} \mathrm{Y}_{1}, \mathrm{P} 2 \mathrm{Y}_{2}, \mathrm{P} 2 \mathrm{Y}_{4}, \mathrm{P} 2 \mathrm{Y}_{6}, \mathrm{~A}_{2 \mathrm{a}}, \mathrm{A}_{2 \mathrm{~b}}, \mathrm{~A}_{1}$, or $\mathrm{A}_{3}$ receptors in whole thickness gut specimens of experimental trinitrobenzene sulfonic acid (TNBS) colitis in rats . Expression of $\mathrm{A}_{1}$ and $A_{3}$ receptor gene products is also altered in a chronic ileitis model of Crohn's disease [106]. The ATP-gated ion channel $\mathrm{P} 2 \mathrm{X}_{3}$ is increased in human IBD [122] as is the case for TNBS colitis [45]. In submucosal neurons of TNBS colitis, there is emergence of a purinergic component of the fast EPSP that is cholinergic in nature in normal animals $[69,70]$. Therefore, there is plasticity of purinergic neurotransmission. Abnormalities in the neural regulation of the gastrointestinal vasculature could contribute to the pathogenesis of IBD. Recent data suggest that reduced 
purinergic neurotransmission via putative $\mathrm{P} 2 \mathrm{X}_{1}$ receptors may underlie a defect in sympathetic regulation of gut vasomotor function during TNBS colitis [68]. Changes in vasomotor function could also impact on secretomotor responses. Further studies are needed to identify the location of these receptors in the gut wall and better understand the functional relevance of these and other receptor abnormalities on secretomotor and vasomotor function in various species and in human gut.

It was recently shown that purinergic gene dysregulation in experimental colitis is sensitive to oral administration of the $\mathrm{A}_{3}$ receptor agonist IB-MECA, a potential therapeutic target for IBD [45]. IB-MECA protects against tissue injury, development of colitis, and prevents dysregulation of $92 \%$ of genes in TNBS colitis, including purine genes. This illustrates a new important benefit of $\mathrm{A}_{3}$ receptor agonists in preventing abnormalities in purine gene expression in colitis. A review by Antonioli et al. [2] discusses the pharmacological modulation of adenosinergic pathways in the therapeutic management of IBD. Adenosine $A_{1}, A_{2 a}$, $A_{2 b}$, and $A_{3}$ receptors are potential therapeutic targets as regulators of gut enteric immune responses and all components of gut motor reflexes [2, 27].

\section{Summary and conclusions}

A secretomotor reflex is activated by mucosal stroking, distension, or chemical stimulation of the mucosa leading to release of 5-HT or other mediators, subsequent activation of IPANs in synaptic communication with interneurons or secretomotor neurons to stimulate chloride and fluid secretion. Inputs from myenteric neurons modulate secretory rates and reflexes, and special neural circuits exist to coordinate secretion with motility and vasomotor functions. All cellular components of secretomotor reflexes express multiple purinergic receptors for adenosine or the nucleotides ATP, ADP, UTP, or UDP. This review focused on the emerging concepts in our understanding of purinergic regulation at these receptors, and in particular of mechanosensory reflexes. Endogenous purines can activate inhibitory $\mathrm{A}_{1}, \mathrm{~A}_{3}$, and $\mathrm{P} 2 \mathrm{Y}_{12}$ receptors or stimulatory $\mathrm{A}_{2}$ and $\mathrm{P}_{2} \mathrm{Y}_{1}$ receptors to modulate 5-HT release. The resting "secretory tone" is influenced by endogenous purines. Stimulatory $\mathrm{P} 2 \mathrm{Y}_{1}$ receptor or inhibitory $\mathrm{A}_{1} / \mathrm{A}_{3}$ receptors are involved in mechanically evoked secretomotor reflexes and a model of neurogenic diarrhea. Recent studies identified the neural and/or non-neural distribution profiles of $\mathrm{P} 2 \mathrm{X}_{2}, \mathrm{P}_{2} \mathrm{X}_{3}, \mathrm{P} 2 \mathrm{X}_{5}, \mathrm{P}_{2} \mathrm{Y}_{1}, \mathrm{P}_{2} \mathrm{Y}_{2}, \mathrm{P}_{2} \mathrm{Y}_{4}, \mathrm{P}_{2} \mathrm{Y}_{6}$, or $\mathrm{P} 2 \mathrm{Y}_{12}$ receptor immunoreactivity in the GI tract suggesting their role in secretomotor function. Significant species and regional differences exist in distribution and function of the receptors. Abnormal expression of purinergic receptors may contribute to functional abnormalities and diarrhea in IBD; functional studies are lacking. Adenosine $\mathrm{A}_{2 \mathrm{a}}$ or $\mathrm{A}_{3}$ receptors are emerging as therapeutic targets in IBD and protect against purinergic receptor abnormalities or profuse diarrhea. Purines are emerging as fundamental regulators of enteric secretomotor reflexes in health and disease.

Future studies should be aimed at better understanding the function of other purinergic receptors expressed in the enteric nervous system or non-neuronal components of the reflex, in both rodents and human gut. More integrative studies on purinergic regulation of chemosensory or mechanosensory secretomotor reflexes are desperately needed. This should pave the way to better understand purine receptor biology, abnormalities in disease states, or as therapeutic targets.

Acknowledgements Many thanks to Drs. Helen J. Cooke, Jacqueline Wunderlich, Jun Ge Yu, Shelly Xue, Jorge Guzman, Huiming Zheng, Asad Javed, and Iveta Grants for their research contributions to the overall field of study. Some cited studies and this review were supported by the National Institutes of Health (NIH) grant numbers R01 DK44179 years $1-13$, a 3 year Fellowship to Dr Jorge Guzman and NCRR 1S10RR11434 and OSU-seed funds.

\section{References}

1. Abbracchio MP, Burnstock G, Boeynaems JM, Barnard EA, Boyer JL, Kennedy C, Knight GE, Fumagalli M, Gachet C, Jacobson KA, Weisman GA (2006) International Union of Pharmacology LVIII: update on the P2Y G protein-coupled nucleotide receptors: from molecular mechanisms and pathophysiology to therapy. Pharmacol Rev 58(3):281-341

2. Antonioli L, Fornai M, Colucci R, Ghisu N, Tuccori M, Del Tacca M, Blandizzi C (2008) Pharmacological modulation of adenosine system: novel options for treatment of inflammatory bowel diseases. Inflamm Bowel Dis 14:566-574

3. Barajas-Lopez C, Espinosa-Luna R, Christofi FL (2000) Changes in intracellular $\mathrm{Ca}^{2+}$ by activation of $\mathrm{P} 2$ receptors in submucosal neurons in short-term cultures. Eur J Pharmacol 409 (3):243-257

4. Bearcroft CP, Perrett D, Farthing MJ (1998) Postprandial plasma 5-hydroxytryptamine in diarrhoea predominant irritable bowel syndrome: a pilot study. Gut 42(1):42-46

5. Bertrand PP (2006) Real-time measurement of serotonin release and motility in guinea pig ileum. J Physiol 577(Pt 2):689-704

6. Bertrand PP (2003) ATP and sensory transduction in the enteric nervous system. Neuroscientist 9(4):243-260

7. Bian X, Ren J, DeVries M, Schnegelsberg B, Cockayne DA, Ford AP, Galligan JJ (2003) Peristalsis is impaired in the small intestine of mice lacking the P2X3 subunit. J Physiol 551(Pt 1):309-322

8. Boserov A, Wang YZ, Javed N, Christofi FL, Cooke HJ (2005) Comparison of adenosine A1 receptor activation on repetitive reflex $\mathrm{Cl}$ secretion coordinated with repetitive muscle activity measured by sonomicrometry and force transducer tension. Gastroenterology 128(4 Suppl 2):A-608

9. Bozarov A, Wang Y-Z, Yu JG, Cooke HJ, Christofi FL (2006) Endogenous adenosine acts at A1 or A3 inhibitory receptors to modulate the stereotype neural-motor behavior of the gut triggered by histamine or distension. Gastroenterology 130(4 Suppl 2):A-29 
10. Brookes SJ, Steele PA, Costa M (1991) Identification and immunohistochemistry of cholinergic and non-cholinergic circular muscle motor neurons in the guinea-pig small intestine. Neuroscience 42(3):863-878

11. Brookes SJ (2001) Classes of enteric nerve cells in the guineapig small intestine. Anat Rec 262(1):58-70

12. Burnstock G (2006) Purinergic signalling. Br J Pharmacol 147 (Suppl 1):S172-S181

13. Cabarrocas J, Savidge TC, Liblau RS (2003) Role of enteric glial cells in inflammatory bowel disease. Glia 41(1):81-93

14. Castelucci P, Robbins HL, Poole DP, Furness JB (2002) The distribution of purine $\mathrm{P} 2 \mathrm{X}(2)$ receptors in the guinea-pig enteric nervous system. Histochem Cell Biol 117(5):415-422

15. Cavalcante IC, Castro MV, Barreto AR, Sullivan GW, Vale M, Almeida PR, Linden J, Rieger JM, Cunha FQ, Guerrant RL, Ribeiro RA, Brito GA (2006) Effect of novel A2A adenosine receptor agonist ATL 313 on Clostridium difficile toxin Ainduced murine ileal enteritis. Infect Immun 74(5):2606-2612

16. Chan HC, Cheung WT, Leung PY, Wu LJ, Chew SB, Ko WH, Wong PY (1996) Purinergic regulation of anion secretion by cystic fibrosis pancreatic duct cells. Am J Physiol 271(2 Pt 1):C469-C477

17. Christofi FL, Kim M, Wunderlich JE, Xue J, Suntres Z, Cardounel AJ, Javed NH, Yu JG, Grants I, Cooke HJ (2004) Endogenous adenosine differentially modulates 5-hydroxytryptamine from a human enterochromaffin cell model. Gastroenterology 127:188202

18. Christofi FL, Wunderlich J, Yu JG, Wang YZ, Xue J, Guzman J, Javed N, Cooke H (2004) Mechanically evoked reflex electrogenic chloride secretion in rat distal colon is triggered by endogenous nucleotides acting at P2Y1, P2Y2, and P2Y4 receptors. J Comp Neurol 469(1):16-36

19. Christofi FL, Zhang H, Yu JG, Guzman J, Xue J, Kim M, Wang YZ, Cooke HJ (2001) Differential gene expression of adenosine $\mathrm{A} 1, \mathrm{~A} 2 \mathrm{a}, \mathrm{A} 2 \mathrm{~b}$, and $\mathrm{A} 3$ receptors in the human enteric nervous system. J Comp Neurol 439(1):46-64

20. Christofi FL (2001) Unlocking mysteries of gut sensory transmission: is adenosine the key? News Physiol Sci 16:201-207

21. Christofi FL, Wood JD (1993) Presynaptic inhibition by adenosine A1 receptors on guinea pig small intestinal myenteric neurons. Gastroenterology 104(5):1420-1429

22. Christofi FL, Tack J, Wood JD (1992) Suppression of nicotinic synaptic transmission by adenosine in myenteric ganglia of the guinea-pig gastric antrum. Eur J Pharmacol 216(1):17-22

23. Clarke LL, Harline MC, Gawenis LR, Walker NM, Turner JT, Weisman GA (2000) Extracellular UTP stimulates electrogenic bicarbonate secretion across CFTR knockout gallbladder epithelium. Am J Physiol Gastrointest Liver Physiol 279(1):G132-G138

24. Coates MD, Mahoney CR, Linden DR, Sampson JE, Chen J, Blaszyk H, Crowell MD, Sharkey KA, Gershon MD, Mawe GM, Moses PL (2004) Molecular defects in mucosal serotonin content and decreased serotonin reuptake transporter in ulcerative colitis and irritable bowel syndrome. Gastroenterology 126(7):1657-1664

25. Cooke HJ, Christofi FL (2006) Enteric neural regulation of mucosal secretion. In: Johnson LR (ed) Physiology of the gastrointestinal tract, 4th edn. Academic, New York, pp 737-762

26. Cooke HJ, Wunderlich J, Christofi FL (2003) "The force be with you": ATP in gut mechanosensory transduction. News Physiol Sci 18:43-49

27. Cooke HJ, Xue J, Yu JG, Wunderlich J, Wang YZ, Guzman J, Javed N, Christofi FL (2004) Mechanical stimulation releases nucleotides that activate $\mathrm{P} 2 \mathrm{Y} 1$ receptors to trigger neural reflex chloride secretion in guinea pig distal colon. J Comp Neurol 469(1):1-15

28. Cooke HJ, Javed N, Christofi FL (2003) Enteric neural reflexes and secretion. In: Bienenstock J, Goetzl EJ, Blennerhassett MG (eds) Autonomic neuroimmunology, 1st edn. CRC Press, Boca Raton, pp 35-59
29. Cooke HJ, Wang Y, Liu CY, Zhang H, Christofi FL (1999) Activation of neuronal adenosine A1 receptors suppresses secretory reflexes in the guinea pig colon. Am J Physiol $276(2$ Pt 1):G451-G462

30. Cooke HJ, Wang YZ, Rogers R (1993) Coordination of Clsecretion and contraction by a histamine $\mathrm{H} 2$-receptor agonist in guinea pig distal colon. Am J Physiol 265(5 Pt 1):G973-G978

31. Coutinho-Silva R, Stahl L, Cheung KK, de Campos NE, de Oliveira Souza C, Ojcius DM, Burnstock G (2005) P2X and P2Y purinergic receptors on human intestinal epithelial carcinoma cells: effects of extracellular nucleotides on apoptosis and cell proliferation. Am J Physiol Gastrointest Liver Physiol 288(5): G1024-G1035

32. Cressman VL, Lazarowski E, Homolya L, Boucher RC, Koller BH, Grubb BR (1999) Effect of loss of P2Y(2) receptor gene expression on nucleotide regulation of murine epithelial $\mathrm{Cl}(-)$ transport. J Biol Chem 274(37):26461-26468

33. Eltzschig HK, Ibla JC, Furuta GT, Leonard MO, Jacobson KA, Enjyoji K, Robson SC, Colgan SP (2003) Coordinated adenine nucleotide phosphohydrolysis and nucleoside signaling in posthypoxic endothelium: role of ectonucleotidases and adenosine A2B receptors. J Exp Med 198(5):783-796

34. Evers BM, Ishizuka J, Townsend CM Jr, Thompson JC (1994) The human carcinoid cell line, BON. A model system for the study of carcinoid tumors. Ann N Y Acad Sci 733:393-406

35. Evers BM, Townsend CM Jr, Upp JR, Allen E, Hurlbut SC, Kim SW, Rajaraman S, Singh P, Reubi JC, Thompson JC (1991) Establishment and characterization of a human carcinoid in nude mice and effect of various agents on tumor growth. Gastroenterology 101(2):303-311

36. Facer P, Knowles CH, Tam PK, Ford AP, Dyer N, Baecker PA, Anand P (2001) Novel capsaicin (VR1) and purinergic (P2X3) receptors in Hirschsprung's intestine. J Pediatr Surg 36(11):16791684

37. Fang $\mathrm{X}, \mathrm{Hu} \mathrm{HZ}$, Gao N, Liu S, Wang GD, Wang XY, Xia Y, Wood JD (2006) Neurogenic secretion mediated by the purinergic P2Y1 receptor in guinea-pig small intestine. Eur J Pharmacol 536 (1-2):113-122

38. Furness JB, Kunze WA, Clerc N (1999) Nutrient tasting and signaling mechanisms in the gut. II. The intestine as a sensory organ: neural, endocrine, and immune responses. Am J Physiol 277(5 Pt 1):G922-G928

39. Furness JB (2000) Types of neurons in the enteric nervous system. J Auton Nerv Syst 81(1-3):87-96

40. Galligan JJ (2004) Enteric P2X receptors as potential targets for drug treatment of the irritable bowel syndrome. Br J Pharmacol 141:1294-1302

41. Gao N, Hu HZ, Zhu MX, Fang X, Liu S, Gao C, Wood JD (2006) The $\mathrm{P} 2 \mathrm{Y}$ purinergic receptor expressed by enteric neurones in guinea-pig intestine. Neurogastroenterol Motil 18(4):316-323

42. Gerber JG, Payne NA (1988) Endogenous adenosine modulates gastric acid secretion to histamine in canine parietal cells. J Pharmacol Exp Ther 244(1):190-194

43. Groschel-Stewart U, Bardini M, Robson T, Burnstock G (1999) P2X receptors in the rat duodenal villus. Cell Tissue Res 297 (1):111-117

44. Gustafsson BI, Bakke I, Tommeras K, Waldum HL (2006) A new method for visualization of gut mucosal cells, describing the enterochromaffin cell in the rat gastrointestinal tract. Scand J Gastroenterol 41:390-395

45. Guzman J, Yu JG, Suntres Z, Bozarov A, Cooke H, Javed N, Auer H, Palatini J, Hassanain HH, Cardounel AJ, Javed A, Grants I, Wunderlich JE, Christofi FL (2006) ADOA3R as a therapeutic target in experimental colitis: proof by validated highdensity oligonucleotide microarray analysis. Inflamm Bowel Dis 12(8):766-789 
46. Gwynne RM, Bornstein JC (2007) Local inhibitory reflexes excited by mucosal application of nutrient amino acids in guinea pig jejunum. Am J Physiol Gastrointest Liver Physiol 292(6): G1660-G1670

47. Hede SE, Amstrup J, Christoffersen BC, Novak I (1999) Purinoceptors evoke different electrophysiological responses in pancreatic ducts. P2Y inhibits $\mathrm{K}(+)$ conductance, and P2X stimulates cation conductance. J Biol Chem 274(45):3178431791

48. Heldsinger AA, Vinik AI, Fox IH (1986) Inhibition of guineapig oxyntic cell function by adenosine and prostaglandins. J Pharmacol Exp Ther 237(2):351-356

49. Hu HZ, Gao N, Lin Z, Gao C, Liu S, Ren J, Xia Y, Wood JD (2001) P2X(7) receptors in the enteric nervous system of guineapig small intestine. J Comp Neurol 440(3):299-310

50. Hu HZ, Gao N, Zhu MX, Liu S, Ren J, Gao C, Xia Y, Wood JD (2003) Slow excitatory synaptic transmission mediated by P2Y1 receptors in the guinea-pig enteric nervous system. J Physiol 550 (Pt 2):493-504

51. Hubel KA (1978) The effects of electrical field stimulation and tetrodotoxin on ion transport by the isolated rabbit ileum. J Clin Invest 62(5):1039-1047

52. Ishiguro $H$, Naruse $S$, Kitagawa M, Hayakawa T, Case RM, Steward MC (1999) Luminal ATP stimulates fluid and HCO3secretion in guinea-pig pancreatic duct. J Physiol 519(Pt 2):551-558

53. Jacobson KA, Gao ZG (2006) Adenosine receptors as therapeutic targets. Nat Rev Drug Discov 5(3):247-264

54. Jenkinson KM, Reid JJ (2000) The P(2)-purinoceptor antagonist suramin is a competitive antagonist at vasoactive intestinal peptide receptors in the rat gastric fundus. Br J Pharmacol 130 (7): $1632-1638$

55. Jijon HB, Walker J, Hoentjen F, Diaz H, Ewaschuk J, Jobin C, Madsen KL (2005) Adenosine is a negative regulator of NFkappaB and MAPK signaling in human intestinal epithelial cells. Cell Immunol 237(2):86-95

56. Kerstan D, Gordjani N, Nitschke R, Greger R, Leipziger J (1998) Luminal ATP induces $\mathrm{K}^{+}$secretion via a P2Y2 receptor in rat distal colonic mucosa. Pflugers Arch 436(5):712-716

57. Khakh BS, Burnstock G, Kennedy C, King BF, North RA, Seguela P, Voigt M, Humphrey PP (2001) International union of pharmacology. XXIV. Current status of the nomenclature and properties of P2X receptors and their subunits. Pharmacol Rev 53(1):107-118

58. Kidd M, Modlin IM, Eick GN, Champaneria MC (2006) Isolation, functional characterization, and transcriptome of Mastomys ileal enterochromaffin cells. Am J Physiol Gastrointest Liver Physiol 291(5):G778-G791

59. Kim M, Cooke HJ, Javed NH, Carey HV, Christofi F, Raybould HE (2001) D-glucose releases 5-hydroxytryptamine from human BON cells as a model of enterochromaffin cells. Gastroenterology 121(6):1400-1406

60. Kimura Y, Turner JR, Braasch DA, Buddington RK (2005) Lumenal adenosine and AMP rapidly increase glucose transport by intact small intestine. Am J Physiol Gastrointest Liver Physiol 289(6):G1007-G1014

61. Kolachala VL, Bajaj R, Chalasani M, Sitaraman SV (2008) Purinergic receptors in gastrointestinal inflammation. Am J Physiol Gastrointest Liver Physiol 294(2):G401-G410

62. Konig J, Schreiber R, Mall M, Kunzelmann K (2002) No evidence for inhibition of $\mathrm{ENaC}$ through CFTR-mediated release of ATP. Biochim Biophys Acta 1565(1):17-28

63. Konturek SJ, Brzozowski T, Pajdo R, Konturek PC, Kwiecien S, Sliwowski Z, Pawlik M, Ptak A, Drozdowicz D, Hahn EG (2001) Gastric preconditioning induced by short ischemia: the role of prostaglandins, nitric oxide and adenosine. Med Sci Monit 7(4):610-621
64. Kwok YN, McIntosh C, Brown J (1990) Augmentation of release of gastric somatostatin-like immunoreactivity by adenosine, adenosine triphosphate and their analogs. J Pharmacol Exp Ther 255(2):781-788

65. Lazarowski ER, Rochelle LG, O'Neal WK, Ribeiro CM, Grubb BR, Zhang V, Harden TK, Boucher RC (2001) Cloning and functional characterization of two murine uridine nucleotide receptors reveal a potential target for correcting ion transport deficiency in cystic fibrosis gallbladder. J Pharmacol Exp Ther 297(1):43-49

66. Lee MG, Schultheis PJ, Yan M, Shull GE, Bookstein C, Chang E, Tse M, Donowitz M, Park K, Muallem S (1998) Membrane-limited expression and regulation of $\mathrm{Na}^{+}-\mathrm{H}^{+}$exchanger isoforms by $\mathrm{P} 2$ receptors in the rat submandibular gland duct. J Physiol 513(Pt 2):341-357

67. Linden DR, Chen JX, Gershon MD, Sharkey KA, Mawe GM (2003) Serotonin availability is increased in mucosa of guinea pigs with TNBS-induced colitis. Am J Physiol Gastrointest Liver Physiol 285(1):G207-G216

68. Lomax AE, O'Reilly M, Neshat S, Vanner SJ (2007) Sympathetic vasoconstrictor regulation of mouse colonic submucosal arterioles is altered in experimental colitis. J Physiol 583 (Pt 2):719-730

69. Lomax AE, Linden DR, Mawe GM, Sharkey KA (2006) Effects of gastrointestinal inflammation on enteroendocrine cells and enteric neural reflex circuits. Auton Neurosci 126-127:250-257

70. Lomax AE, Fernández E, Sharkey KA (2005) Plasticity of the enteric nervous system during intestinal inflammation. Neurogastroenterol Motil 17(1):4-15

71. Lomax AE, Furness JB (2000) Neurochemical classification of enteric neurons in the guinea-pig distal colon. Cell Tissue Res 302(1):59-72

72. Luo X, Zheng W, Yan M, Lee MG, Muallem S (1999) Multiple functional P2X and P2Y receptors in the luminal and basolateral membranes of pancreatic duct cells. Am J Physiol 277(2 Pt 1): C205-C215

73. Madara JL, Nash S, Parkos C (1991) Neutrophil-epithelial cell interactions in the intestine. Adv Exp Med Biol 314:329-334

74. Matos JE, Sorensen MV, Geyti CS, Robaye B, Boeynaems JM, Leipziger J (2007) Distal colonic $\mathrm{Na}(+)$ absorption inhibited by luminal P2Y(2) receptors. Pflugers Arch 454(6):977-987

75. Matos JE, Robaye B, Boeynaems JM, Beauwens R, Leipziger J (2005) $\mathrm{K}^{+}$secretion activated by luminal P2Y2 and P2Y4 receptors in mouse colon. J Physiol 564(Pt 1):269-279

76. McAlroy HL, Ahmed S, Day SM, Baines DL, Wong HY, Yip CY, Ko WH, Wilson SM, Collett A (2000) Multiple P2Y receptor subtypes in the apical membranes of polarized epithelial cells. Br J Pharmacol 131(8):1651-1658

77. Naganuma M, Wiznerowicz EB, Lappas CM, Linden J, Worthington MT, Ernst PB (2006) Cutting edge: critical role for A2A adenosine receptors in the T cell-mediated regulation of colitis. J Immunol 177(5):2765-2769

78. Nahum V, Zundorf G, Levesque SA, Beaudoin AR, Reiser G, Fischer B (2002) Adenosine 5'-O (1-boranotriphosphate) derivatives as novel P2Y(1) receptor agonists. J Med Chem 45 (24):5384-5396

79. Namiot Z, Rutkiewicz J, Stasiewicz J, Gorski J (1990) Adenosine deaminase activity in the human gastric mucosa in relation to acid secretion. Digestion 45(3):172-175

80. Namiot Z, Rutkiewicz J, Stasiewicz J, Baranczuk E, Marcinkiewicz M (1991) Adenosine deaminase activity in the gastric mucosa in patients with gastric ulcer. Effects of ranitidine and sucralfate. Eur J Pharmacol 205(1):101-103

81. Nguyen TD, Moody MW, Savard CE, Lee SP (1998) Secretory effects of ATP on nontransformed dog pancreatic duct epithelial cells. Am J Physiol 275(1 Pt 1):G104-G113 
82. Odashima M, Bamias G, Rivera-Nieves J, Linden J, Nast CC, Moskaluk CA, Marini M, Sugawara K, Kozaiwa K, Otaka M, Watanabe S, Cominelli F (2005) Activation of A2A adenosine receptor attenuates intestinal inflammation in animal models of inflammatory bowel disease. Gastroenterology 129(1):26-33

83. Odashima M, Otaka M, Jin M, Komatsu K, Wada I, Horikawa Y, Matsuhashi T, Hatakeyama N, Oyake J, Ohba R, Watanabe S, Linden J (2006) Attenuation of gastric mucosal inflammation induced by aspirin through activation of A2A adenosine receptor in rats. World J Gastroenterol 12(4):568-573

84. Pan H, Gershon MD (2000) Activation of intrinsic afferent pathways in submucosal ganglia of the guinea pig small intestine. J Neurosci 20(9):3295-3309

85. Poole DP, Castelucci P, Robbins HL, Chiocchetti R, Furness JB (2002) The distribution of $\mathrm{P} 2 \mathrm{X} 3$ purine receptor subunits in the guinea pig enteric nervous system. Auton Neurosci 101(1-2):3947

86. Puurunen J, Ruoff HJ, Schwabe U (1987) Lack of direct effect of adenosine on the parietal cell function in the rat. Pharmacol Toxicol 60(4):315-317

87. Raybould HE, Cooke HJ, Christofi FL (2004) Sensory mechanisms: transmitters, modulators and reflexes. Neurogastroenterol Motil 16(Suppl 1):60-63

88. Reed DE, Vanner S (2007) Mucosal stimulation activates secretomotor neurons via long myenteric pathways in guinea pig ileum. Am J Physiol Gastrointest Liver Physiol 292(2):G608-G614

89. Rivkees SA, Reppert SM (1992) RFL9 encodes an A2badenosine receptor. Mol Endocrinol 6(10):1598-1604

90. Robaye B, Ghanem E, Wilkin F, Fokan D, Van Driessche W, Schurmans S, Boeynaems JM, Beauwens R (2003) Loss of nucleotide regulation of epithelial chloride transport in the jejunum of P2Y4-null mice. Mol Pharmacol 63(4):777-783

91. Rodrigues RJ, Almeida T, Richardson PJ, Oliveira CR, Cunha RA (2005) Dual presynaptic control by ATP of glutamate release via facilitatory $\mathrm{P} 2 \mathrm{X} 1, \mathrm{P} 2 \mathrm{X} 2 / 3$, and $\mathrm{P} 2 \mathrm{X} 3$ and inhibitory $\mathrm{P} 2 \mathrm{Y} 1$, $\mathrm{P} 2 \mathrm{Y} 2$, and/or P2Y4 receptors in the rat hippocampus. J Neurosci 25(27):6286-6295

92. Roman RM, Fitz JG (1999) Emerging roles of purinergic signaling in gastrointestinal epithelial secretion and hepatobiliary function. Gastroenterology 116(4):964-979

93. Ruan HZ, Burnstock G (2004) P2X2 and P2X3 receptor expression in the gallbladder of the guinea pig. Auton Neurosci 111(2):89-96

94. Ruan HZ, Burnstock G (2005) The distribution of P2X5 purinergic receptors in the enteric nervous system of mouse. Cell Tissue Res 319(2):191-200

95. Ruhl A, Nasser Y, Sharkey KA (2004) Enteric glia. Neurogastroenterol Motil 16(Suppl 1):44-49

96. Salter KD, Fitz JG, Roman RM (2000) Domain-specific purinergic signaling in polarized rat cholangiocytes. Am J Physiol Gastrointest Liver Physiol 278(3):G492-G500

97. Saslow SB, Scolapio JS, Camilleri M, Forstrom LA, Thomforde GM, Burton DD, Rubin J, Pitot HC, Zinsmeister AR (1998) Medium-term effects of a new 5HT3 antagonist, alosetron, in patients with carcinoid diarrhoea. Gut 42(5):628-634

98. Sanchez-Pozo A, Gil A (2002) Nucleotides as semiessential nutritional components. Br J Nutr 87(Suppl 1):S135-S137

99. Sarwar G, Brule D (1991) Assessment of the uricogenic potential of processed foods based on the nature and quantity of dietary purines. Prog Food Nutr Sci 15(3):159-181

100. Schlenker T, Romac JM, Sharara AI, Roman RM, Kim SJ, LaRusso N, Liddle RA, Fitz JG (1997) Regulation of biliary secretion through apical purinergic receptors in cultured rat cholangiocytes. Am J Physiol 273(5 Pt 1):G1108-G1117

101. Schreiber R, Konig J, Sun J, Markovich D, Kunzelmann K (2003) Effects of purinergic stimulation, CFTR and osmotic stress on amiloride-sensitive $\mathrm{Na}+$ transport in epithelia and Xenopus oocytes. J Membr Biol 192(2):101-110

102. Schwiebert EM, Egan ME, Hwang TH, Fulmer SB, Allen SS, Cutting GR, Guggino WB (1995) CFTR regulates outwardly rectifying chloride channels through an autocrine mechanism involving ATP. Cell 81(7):1063-1073

103. Sitaraman SV, Merlin D, Wang L, Wong M, Gewirtz AT, SiTahar M, Madara JL (2001) Neutrophil-epithelial crosstalk at the intestinal lumenal surface mediated by reciprocal secretion of adenosine and IL-6. J Clin Invest 107(7):861-869

104. Strohmeier GR, Lencer WI, Patapoff TW, Thompson LF, Carlson SL, Moe SJ, Carnes DK, Mrsny RJ, Madara JL (1997) Surface expression, polarization, and functional significance of CD73 in human intestinal epithelia. J Clin Invest 99(11):2588-2601

105. Suarez-Huerta N, Pouillon V, Boeynaems J, Robaye B (2001) Molecular cloning and characterization of the mouse P2Y4 nucleotide receptor. Eur J Pharmacol 416(3):197-202

106. Sundaram U, Hassanain H, Suntres Z, Yu JG, Cooke HJ, Guzman J, Christofi FL (2003) Rabbit chronic ileitis leads to up-regulation of adenosine A1/A3 gene products, oxidative stress, and immune modulation. Biochem Pharmacol 65 (9):1529-1538

107. Vank C, Fromter E, Kottra G (1999) The activation of an apical Cl- conductance by extracellular ATP is potentiated by genistein in Necturus gallbladder epithelium. Pflugers Arch 438(4):497501

108. Van Nassauw L, Brouns I, Adriaensen D, Burnstock G, Timmermans JP (2002) Neurochemical identification of enteric neurons expressing $\mathrm{P} 2 \mathrm{X}(3)$ receptors in the guinea-pig ileum. Histochem Cell Biol 118(3):193-203

109. Van Nassauw L, Costagliola A, Van Op den Bosch J, Cecio A, Vanderwinden JM, Burnstock G, Timmermans JP (2006) Region-specific distribution of the $\mathrm{P} 2 \mathrm{Y} 4$ receptor inenteric glial cells and interstitial cells of Cajal within the guinea-pig gastrointestinal tract. Auton Neurosci 126-127:299-306

110. von Kugelgen I (2006) Pharmacological profiles of cloned mammalian P2Y-receptor subtypes. Pharmacol Ther 110(3):415-432

111. Vulchanova L, Arvidsson U, Riedl M, Wang J, Buell G, Surprenant A, North RA, Elde R (1996) Differential distribution of two ATPgated channels (P2X receptors) determined by immunocytochemistry. Proc Natl Acad Sci U S A 93(15):8063-8067

112. Weber E, Neunlist M, Schemann M, Frieling T (2001) Neural components of distension-evoked secretory responses in the guinea-pig distal colon. J Physiol 536(Pt 3):741-751

113. Wood JD (2006) The enteric purinergic P2Y(1) receptor. Curr Opin Pharmacol 6(6):564-570

114. Wunderlich J, Xue J, Cooke HJ, Christofi FL (2004) Visualization and mapping of mechanosensitive $\mathrm{P} 2 \mathrm{X}$ receptors in the human BON-enterochromaffin cell model. Gastroenterology 126 (Suppl 2):A-412

115. Wunderlich JE, Needleman BJ, Chen Z, Yu JG, Wang YZ, Grants I, Mikami D, Melvin WS, Cooke HJ, Christofi FL (2008) Dual purinergic synaptic transmission in the human enteric nervous system. Am J Physiol Gastrointest Liver Physiol 294(2): G554-G566

116. Wynn G, Rong W, Xiang Z, Burnstock G (2003) Purinergic mechanisms contribute to mechanosensory transduction in the rat colorectum. Gastroenterology 125(5):1398-1409

117. Xiang Z, Burnstock G (2006) Distribution of P2Y(6) and P2Y (12) receptor: their colocalization with calbindin, calretinin and nitric oxide synthase in the guinea pig enteric nervous system. Histochem Cell Biol 125(4):327-336

118. Xiang Z, Burnstock G (2005) Distribution of P2Y2 receptors in the guinea pig enteric nervous system and its coexistence with $\mathrm{P} 2 \mathrm{X} 2$ and $\mathrm{P} 2 \mathrm{X} 3$ receptors, neuropeptide $\mathrm{Y}$, nitric oxide synthase and calretinin. Histochem Cell Biol 124(5):379-390 
119. Xiang Z, Burnstock G (2004) P2X2 and P2X3 purinoceptors in the rat enteric nervous system. Histochem Cell Biol 121(3):169179

120. Xue J Christofi FL, Cooke HJ (2007) P2Y12 receptors inhibit mechanosensitive release of 5-HT from human carcinoid BON cells. Gastroenterology 132:A547

121. Xue J, Christofi FL, Cooke HJ (2007) Mechanosensitive release of calcium or 5HT: P2Y1 receptor over-expression in human Bon cells. Gastroenterology 132(Suppl 2):A-242

122. Yiangou Y, Facer P, Baecker PA, Ford AP, Knowles CH, Chan CL, Williams NS, Anand P (2001) ATP-gated ion channel P2X
(3) is increased in human inflammatory bowel disease. Neurogastroenterol Motil 13(4):365-369

123. Yip L, Kwok YN (2004) Role of adenosine A2A receptor in the regulation of gastric somatostatin release. J Pharmacol Exp Ther 309(2):804-815

124. Yip L, Leung HC, Kwok YN (2004) Effect of omeprazole on gastric adenosine $\mathrm{A} 1$ and $\mathrm{A} 2 \mathrm{~A}$ receptor gene expression and function. J Pharmacol Exp Ther 311(1):180-189

125. Yip L, Leung HC, Kwok YN (2004) Role of adenosine A1 receptor in the regulation of gastrin release. J Pharmacol Exp Ther 310(2):477-487 